\title{
Measuring adolescent friendly health services in India: A scoping review of evaluations
}

\author{
Andrea J. Hoopes ${ }^{1 *}$, Paras Agarwal ${ }^{2}$, Sheana Bull ${ }^{3,4}$ and Venkatraman Chandra-Mouli ${ }^{5}$
}

\begin{abstract}
Background: Initiatives to promote adolescent friendly health services (AFHS) have been taking place in India and many low- and middle-income countries for nearly two decades. Evaluations of these initiatives have been placed in the public arena from time to time, but little is known about what they say about the overall situation on AFHS in India. This study aimed to describe how efforts to provide AFHS in India have been evaluated, how well they have been evaluated, and what their findings and implications are.
\end{abstract}

Methods: We conducted a scoping review of evaluations of AFHS initiatives in India from 2000 to 2014. An electronic search was carried out in Medline and EMBASE. A manual search of grey literature was also performed, and experts were contacted in order to obtain additional manuscripts and reports.

Results: Thirty evaluation reports were identified representing a broad geographic distribution. Evaluations have focused on government-sponsored AFHS programmes or independent non-governmental organization (NGO) initiatives to strengthen government services. The evaluations primarily measured programme outputs (e.g. quality and service utilization) and health behavioural outcomes (e.g. condom use). Study designs were commonly descriptive or quasi-experimental. Most evaluations found improvement in quality and utilization of services, and some demonstrated an increase in adolescent knowledge or health behaviours. Few measured positive project/ programme results such as older age at first pregnancy. Strengths of evaluations were clear objectives, frequent use of multiple data sources, and assessment of programmatic outputs as well as health outcomes. Weaknesses were lack of consistency and quality.

Conclusions: Our findings confirm that a number of evaluations of AFHS initiatives in India have been carried out. They point to service quality and in behavioural improvements in adolescents. However, their lack of consistency hinders comparison across sites, and their uneven quality means that their findings need to be interpreted with caution.

Keywords: Adolescent friendly health services, Contraception, Adolescent sexual and reproductive health, Reproductive health services, Systematic review, India, Programme evaluation

\footnotetext{
*Correspondence: andrea.hoopes@childrenscolorado.org

${ }^{1}$ Department of Pediatrics, University of Colorado School of Medicine, 13123

East 16th Avenue, Box B025, Aurora, CO, USA

Full list of author information is available at the end of the article
} 


\section{Plain English summary}

Adolescents make up one-fifth of India's population. India's government has prioritized efforts to make health services more adolescent friendly. A number of individual studies and evaluations have been carried out and published, but little is known about what they say as a whole. The purpose of our study was to explore the range and results of evaluations of adolescent friendly health services in India.

We conducted a review of publicly-available evaluations of adolescent friendly health service programmes or projects in India from 2000 to 2014 . We found thirty evaluations describing initiatives led by government agencies and non-governmental organizations. We summarized the methods and findings of these evaluations using a standard framework. We learned that evaluations were highly variable in measuring programme processes, outputs, or health impacts. Most evaluations found improvement in quality of services and some showed an increased in adolescents' knowledge and sexual health behaviours.

Our study concluded that evaluations of adolescent friendly initiatives are taking place in India and demonstrating positive health benefits for adolescents. We recommend that evaluation methods be standardized to ensure quality and comparability.

\section{Background}

Improving the reproductive and sexual health (RSH) of adolescents is a key component of India's National Health Mission [1, 2]. This paper examines evaluations of government and non-government organization (NGO) initiatives to increase access to quality RSH services by adolescents and young people in India.
Adolescents constitute over $20 \%$ of India's population. These young people face a number of $\mathrm{RSH}$ problems, such as risk for early and unplanned pregnancy and vulnerability to sexually transmitted infections, including HIV [3, 4]. India's Ministry of Health and Family Welfare (hereafter called "the Ministry") addressed these problems in 2005 by formulating its national Adolescent Reproductive and Sexual Health (Adolescent RSH) policy and guidelines within the context of the National Health Mission [5]. Measures were subsequently taken to support their implementation [1]. Officials in some states and union territories began applying the Adolescent RSH policy and guidelines, and NGOs escalated their efforts as well.

A growing body of reports and articles have documented efforts to make RSH services more equitable, available, acceptable, appropriate, and effective-all characteristics of adolescent friendly health services (AFHS) as defined by the World Health Organization (WHO) [6]. In its implementation guide for ARSH, the Ministry enumerated seven standards for providing AFHS (Table 1) [1]. In 2014, the Ministry launched Rashtriya Kishor Swasthya Karyakram, the National Adolescent Health Programme), which expanded the scope of adolescent health programming beyond RSH but maintains AFHS in clinics as a key element of its list of programme components [7]. To date, there is limited knowledge of how these policies and programmes to increase access to quality RSH services have been evaluated and what lessons have been learned thus far.

Our study examined how these expanded efforts to promote AFHS have been evaluated in order to map efforts thus far and identify strategies to perform these

Table 1 Standards from Government of India Implementation Guide for Adolescent Friendly Health Services ${ }^{\text {a }}$

\begin{tabular}{|c|c|}
\hline Standards & Issues covered \\
\hline 1. Availability of specific service package & $\begin{array}{l}\text { - Dedicated ARSH clinic (Preventive, Promotive, Curative, and Referral) } \\
\text { - Outreach programme for adolescents }\end{array}$ \\
\hline 2. Delivery of effective services & $\begin{array}{l}\text { - Adequate manpower } \\
\text { - Guidelines and Standard Operating Procedures } \\
\text { - Equipment and supplies }\end{array}$ \\
\hline 3. Conducive environment at clinic & $\begin{array}{l}\text { - Location and timing } \\
\text { - Basic amenities } \\
\text { - Privacy and confidentiality }\end{array}$ \\
\hline 4. Sensitive and non-judgemental providers & $\begin{array}{l}\text { - Attitude } \\
\text { - Communication skills }\end{array}$ \\
\hline 5. Enabling environment in community & $\begin{array}{l}\text { - Sensitization } \\
\text { - Distribution of Information Education \& Communication (IEC) materia }\end{array}$ \\
\hline 6. Adolescents informed on availability of services & $\begin{array}{l}\text { - Signboard } \\
\text { - IEC in school, public places } \\
\text { - Folk and multimedia }\end{array}$ \\
\hline 7. MIS in place & $\begin{array}{l}\text { - Recording and reporting } \\
\text { - Supervision }\end{array}$ \\
\hline
\end{tabular}

${ }^{a}$ (National Rural Health Mission. Implementation guide on RCH II adolescent reproductive sexual health strategy for state and district programme managers [Internet]. 2006. Available from: http://www.searo.who.int/entity/child_adolescent/topics/adolescent_health/rch_asrh_india.pdf 
evaluations. Specifically, we sought to answer the following questions:

- Where and when have evaluations/studies of AHFS initiatives been carried out?

- Who has conducted these evaluations/studies?

- For what purpose have these evaluations/studies been conducted?

- What design and methods have been used to carry out these evaluations/studies?

- What was the nature and extent of facilities and clients included in these evaluations/studies?

- What were the main findings of these evaluations/ studies?

Our goal is to improve the quality and impact of population-based AFHS efforts and to gain knowledge for implementation in other settings.

\section{Methods}

\section{Literature search}

We conducted a systematic search of publicly available peer-reviewed articles and reports from January 1, 2000 to August 1, 2014. We searched Medline and EMBASE electronic databases using medical subject heading $(\mathrm{MeSH})$ terms "adolescent health services" or adolescent and young adult age-limited "health services," "preventive health services," or "school health services." We restricted our search to peer-reviewed studies and evaluations performed in India. Detailed search strategies are in Appendices 1 and 2. We used the same key words to search websites of organizations engaged in adolescent health service activities in India, including United Nations agencies, international and indigenous NGOs, bilateral agencies, and foundations. In addition, we searched the websites of professional associations and the Ministry at national and state/district levels for relevant publications. Finally, we reviewed the reference lists of articles and reports obtained to identify any additional publications that may have been missed.

\section{Inclusion and exclusion criteria}

We established inclusion criteria as any report that described an evaluation of an initiative to improve health services for adolescents in India. We included initiatives in all types of health facilities-including those for all ages and those dedicated to adolescents and those operated by government or NGOs. Our primary focus was on facility-based initiatives directed at individuals ten to nineteen years, and on health service provision (i.e. the provision of preventive, curative and rehabilitative services by a trained health worker). We defined evaluation as "the systematic collection of information about the activities, characteristics, and outcomes of programmes [for adolescents] to make judgments about the program, improve program effectiveness, and/or inform decisions about future program development" [7]. We defined research as "the scientific investigation of how social factors, financing systems, organizational structures and processes, health technologies and personal behaviours affect adolescent access to health care, the quality and cost of health care, and health and well-being of adolescent recipients of services" [8]. Because we were primarily interested in results of programmes, we did not include formative or input evaluations that informed programme development and focused our review instead on a range of evaluation types from process to output, outcome and impact evaluations (see Fig. 1). We used standard Preferred Reporting Items for Systematic Reviews and Meta-Analyses (PRISMA) flow diagram to describe the inclusion and exclusion process [9]. PRISMA is an evidence-based flow diagram of the minimum

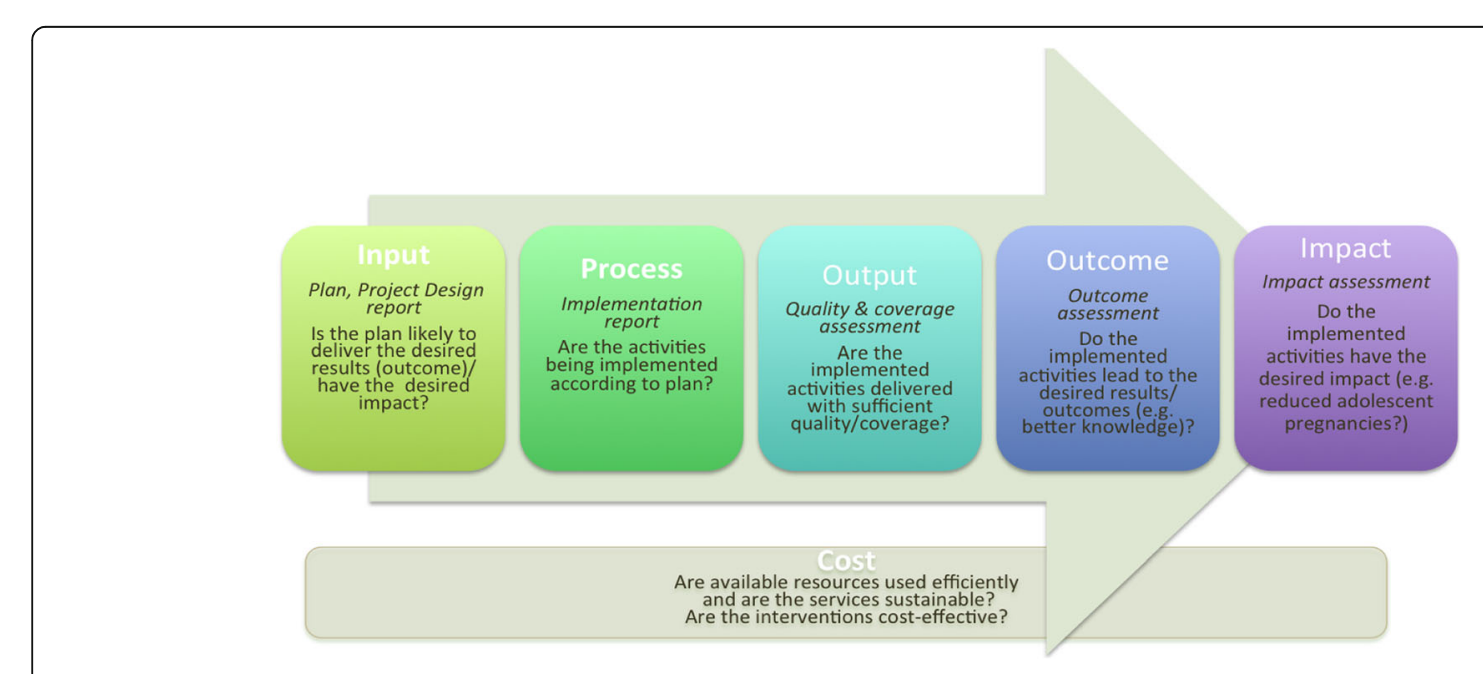

Fig. 1 Evaluation logic models 
items for reporting in systematic reviews and metaanalyses designed to help authors improve reporting. Human subjects review was not necessary given that our review protocol did not directly involve human participants.

\section{Data analysis}

Two authors reviewed all reports and entered data from those meeting initial inclusion criteria into an evidence table adapted from PRISMA statement elements [10]. We categorized data based on geographic region where the study/evaluation was conducted, year, institution/ organization that carried it out, its objectives, its design and methods (see Table 2 for a definition of the types of evaluation or research designs employed across the selected evaluations), nature of health facilities (hospital/ clinic, government/non-government), and number of health facilities and/or users studied. We identified the type of study/evaluation they employed organized them into four broad categories (see categories illustrated in the logic model Fig. 1). These categories included findings (when present for each category) specific to process (programme design, fidelity of implementation of the programme), outputs (including quality and coverage/ reach of services), health behaviour outcomes, and programme results/impact measured by evaluation. Data entered into the table were discussed with all authors to reach consensus on characteristics and findings of each evaluation. Following data abstraction, we reviewed trends specific to the categories described above and developed primary results for each category through discussions among authors.

We utilized the Revised Standards for Quality Improvement Reporting Excellence to assess the quality of each publication [11]. The SQUIRE guidelines were developed and refined through a systematic vetting process with input from an expert panel and through public feedback $[12,13]$ and provide a framework for reporting new knowledge about how to improve healthcare. Two authors rated each evaluation using an adapted quality assessment scoring approach where each adapted SQUIRE criteria met by an evaluation report resulted in

Table 2 Evaluation or study designs

\begin{abstract}
Descriptive: Describes client or programme/project characteristics, service utilization, client satisfaction, and program processes, outputs, and outcomes without a comparison group/site.
\end{abstract}

Quasi-experimental: Compares an intervention group/site to a control group/site without randomization or compares an intervention group/ site to itself using measurements pre- and post-implementation of programme/project.

Experimental: Compares an intervention group to a control group using randomization.

Feasibility testing: Evaluates and analyses the potential of a proposed programme/project.
1 point. A maximum score for meeting all criteria was 15. Two authors independently scored each report, and mean scores and inter-rater reliability were calculated and compared using a Mann-Whitney comparison and kappa statistic.

\section{Results}

We identified 161 publications in our initial database search and thirty-three additional publications from our grey literature search. The process we used to move from this to the thirty presented here is described using a PRISMA flow diagram (Appendix 3). After removing duplicates, we screened titles and abstracts of 194 publications, of which 141 were excluded. Of the remaining 53 full-text articles and reports reviewed, we excluded twenty-three based on: not examining health service provision $(N=14)$, not specific to adolescents or adolescent-friendly health services $(N=5)$, study/evaluation of programme distributing a health commodity (e.g. iron supplementation) outside of clinical service context/venue $(N=3)$, or other $(N=1$ non-systematic review). Of the remaining thirty publications, eighteen were published as reports and twelve as peerreviewed research studies. Characteristics and main findings of evaluation reports (labelled with letters AS) are found in (Tables 3 and 4) and of peer-reviewed articles (labelled with numbers 1-12) in (Tables 5 and $6)$, respectively.

\section{Where and when have the evaluations/studies been carried out?}

We found a broad geographic distribution of the thirty studies/evaluations. We identified eight in Maharashtra, five in Bihar, three in Haryana, two in Delhi, Gujarat, and Uttar Pradesh, and one each in Odisha, Rajasthan, and Uttarakhand. We also identified five that covered multiple states and union territories. Some evaluations/ studies analysed data from the same project (e.g., PRACHAR), at different time points and with varying study designs. See Fig. 2 for a map illustrating where specific evaluations/studies were carried out. The majority of reports/articles were published in the latter half of the inclusion time period of 2000 to 2014 with only five $(A, B ; 1,2,3)$ published before 2008. Time from AFHS implementation through data collection to publication of report, when indicated, ranged from 1 to 6 years.

\section{Who has conducted these evaluations/studies?}

NGO's conducted fourteen of the thirty evaluations/ studies $(46 \%)$. Of those, five $(D, M, N ; 3,12)$ were conducted by indigenous NGOs and nine $(A, B, I, R$; $1,5,8,9,11)$ by international NGOs. Other bodies included academic institutions $(S, F, K, P, Q, S ; 2,4,6,7,10)$, consulting agencies $(\mathrm{E}, \mathrm{G}, \mathrm{L})$, a government $(C)$ or a 


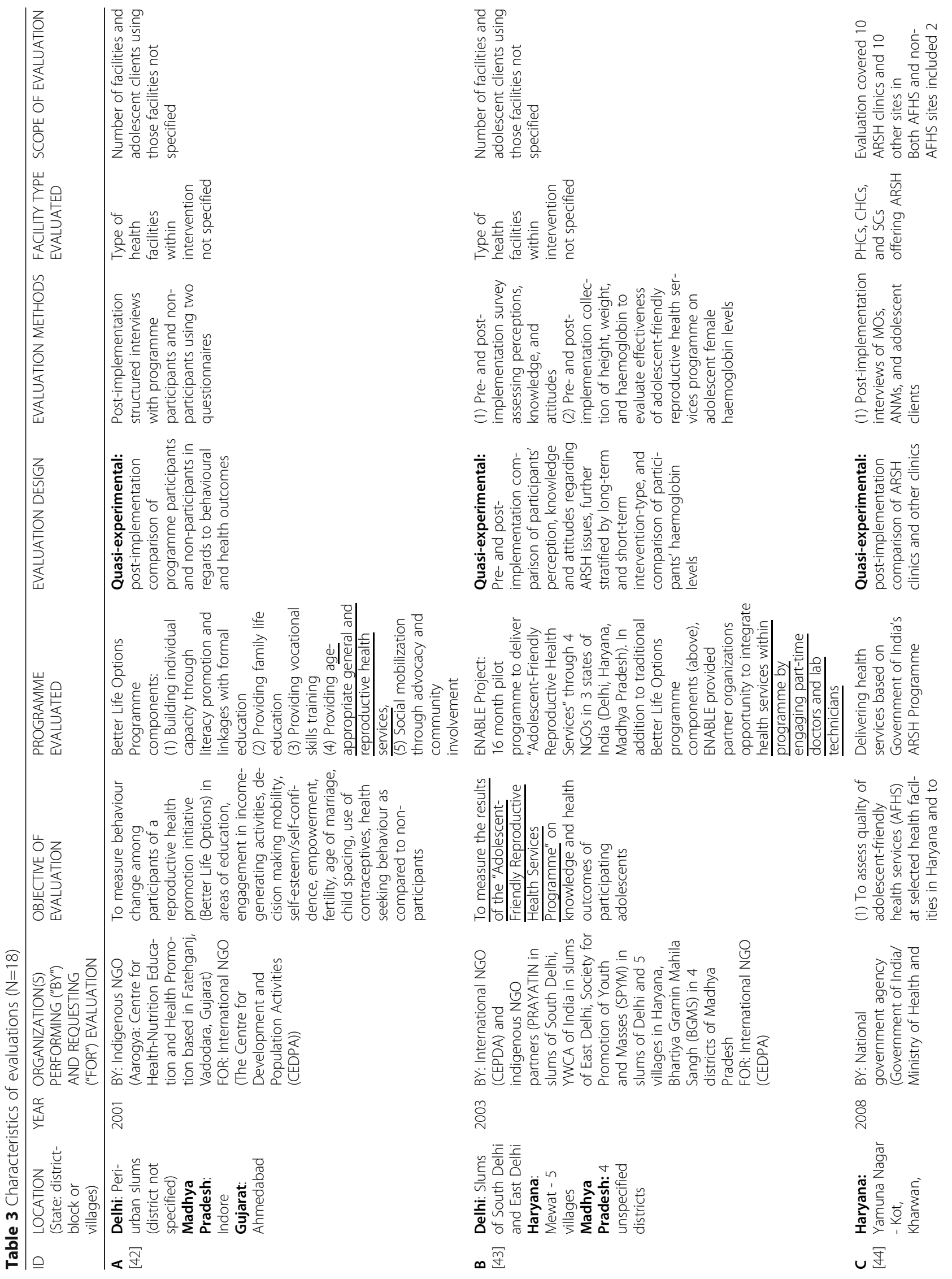




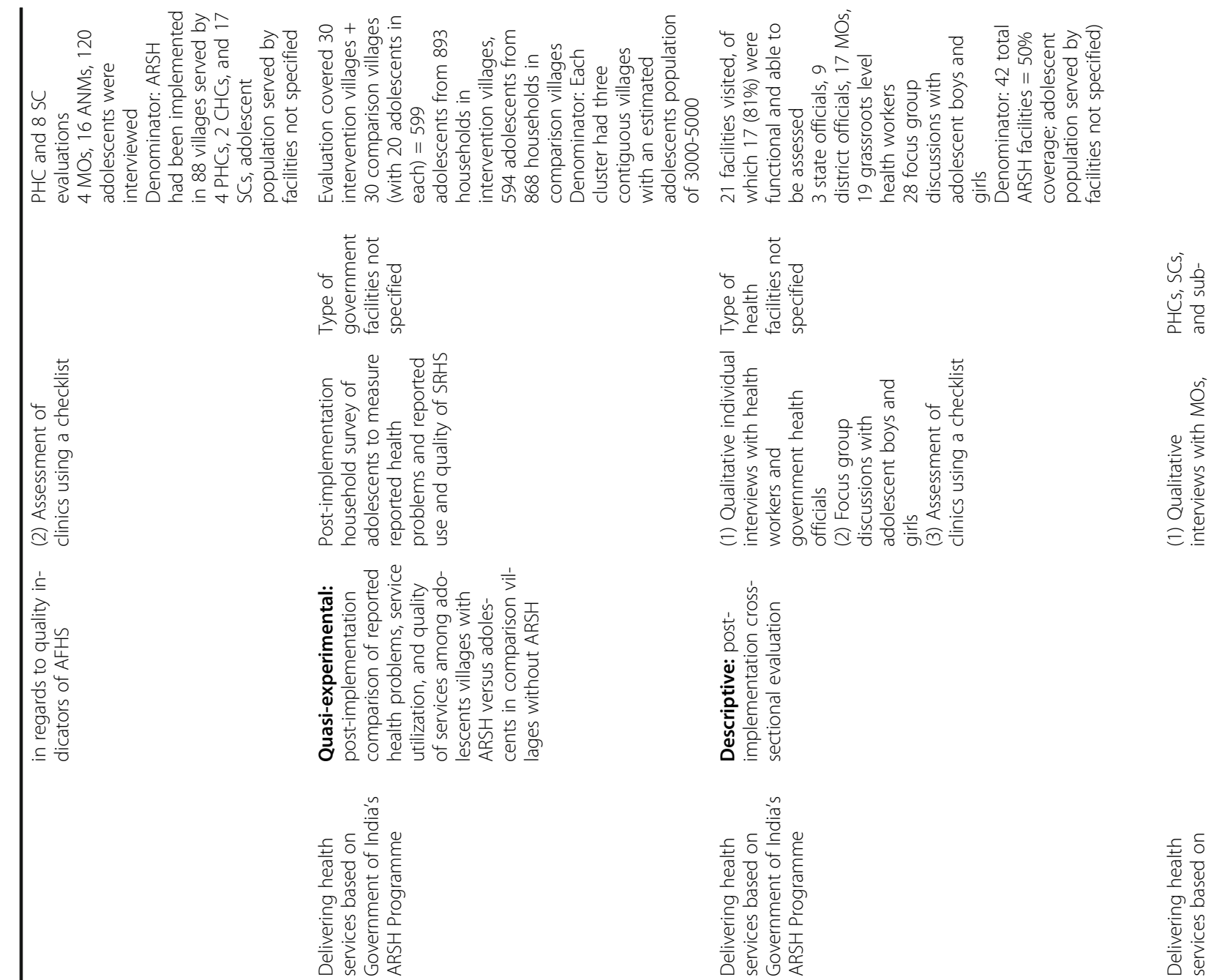

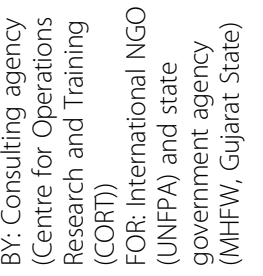

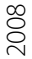

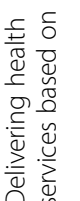

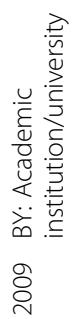

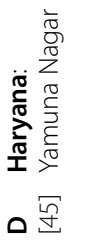

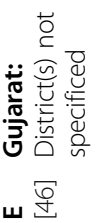




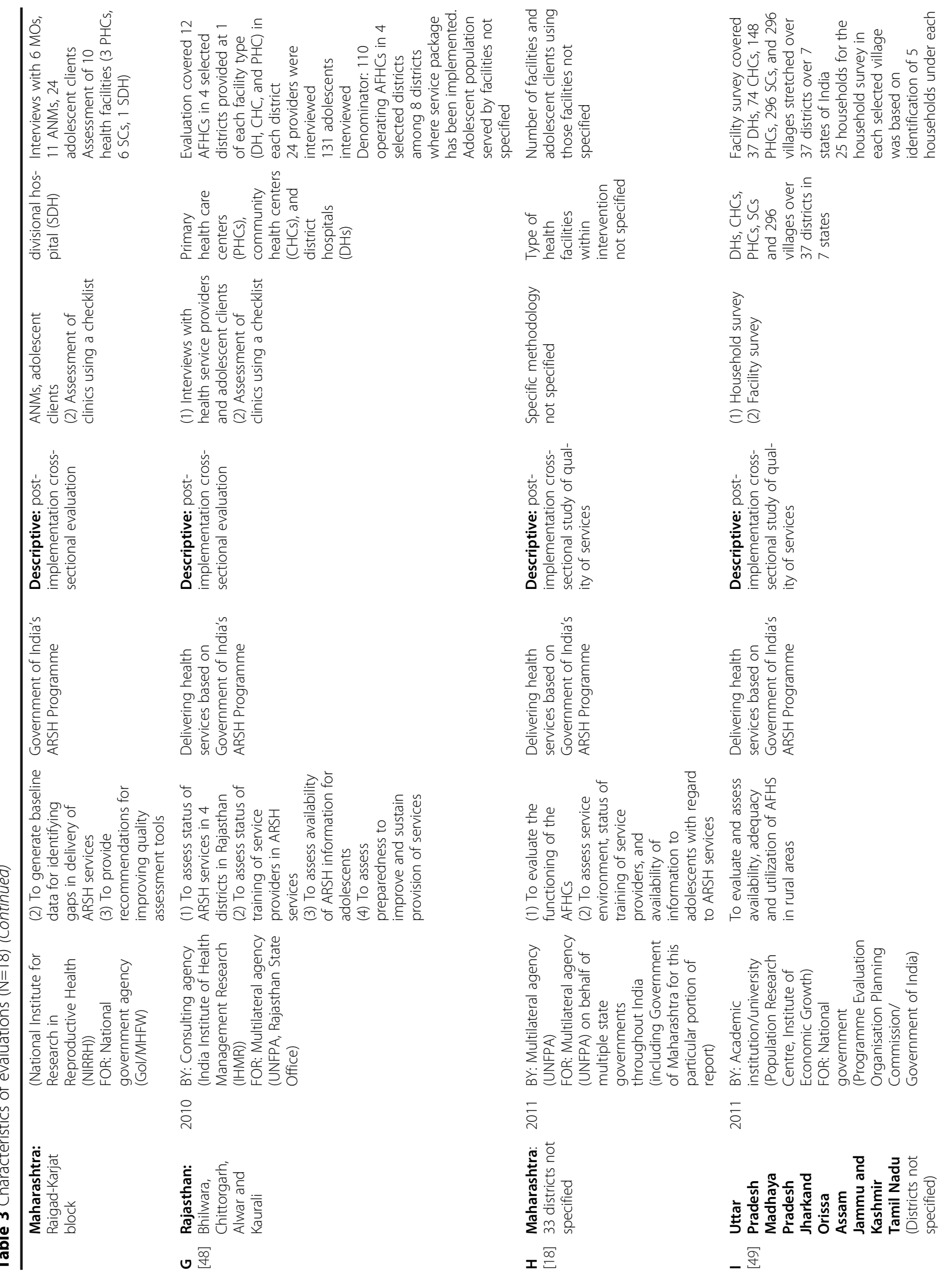




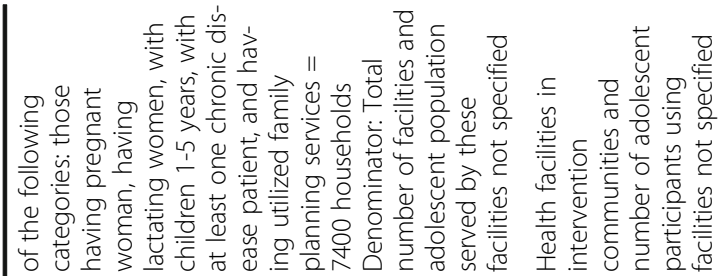

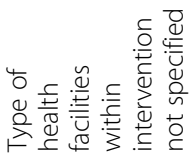

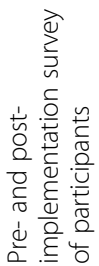

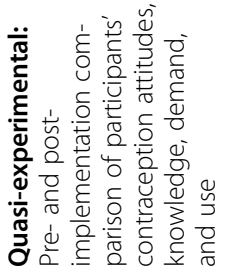

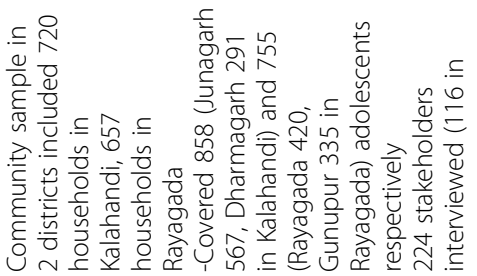

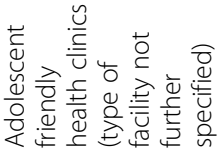

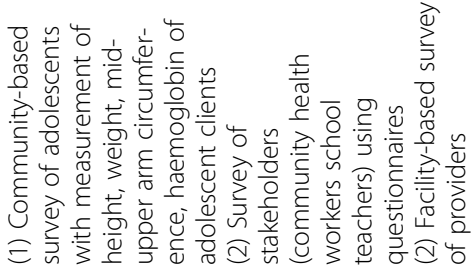

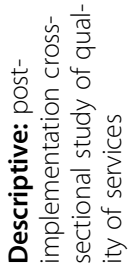

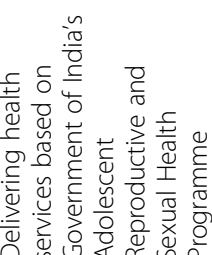

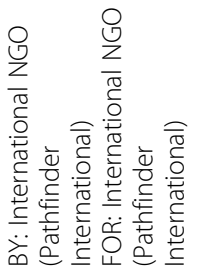

$\bar{\Sigma}$

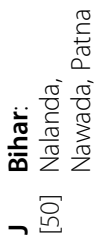

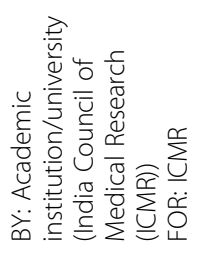

กั

它

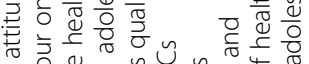

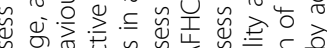

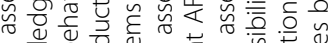

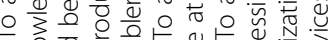

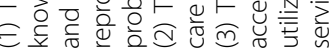

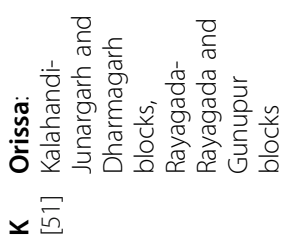




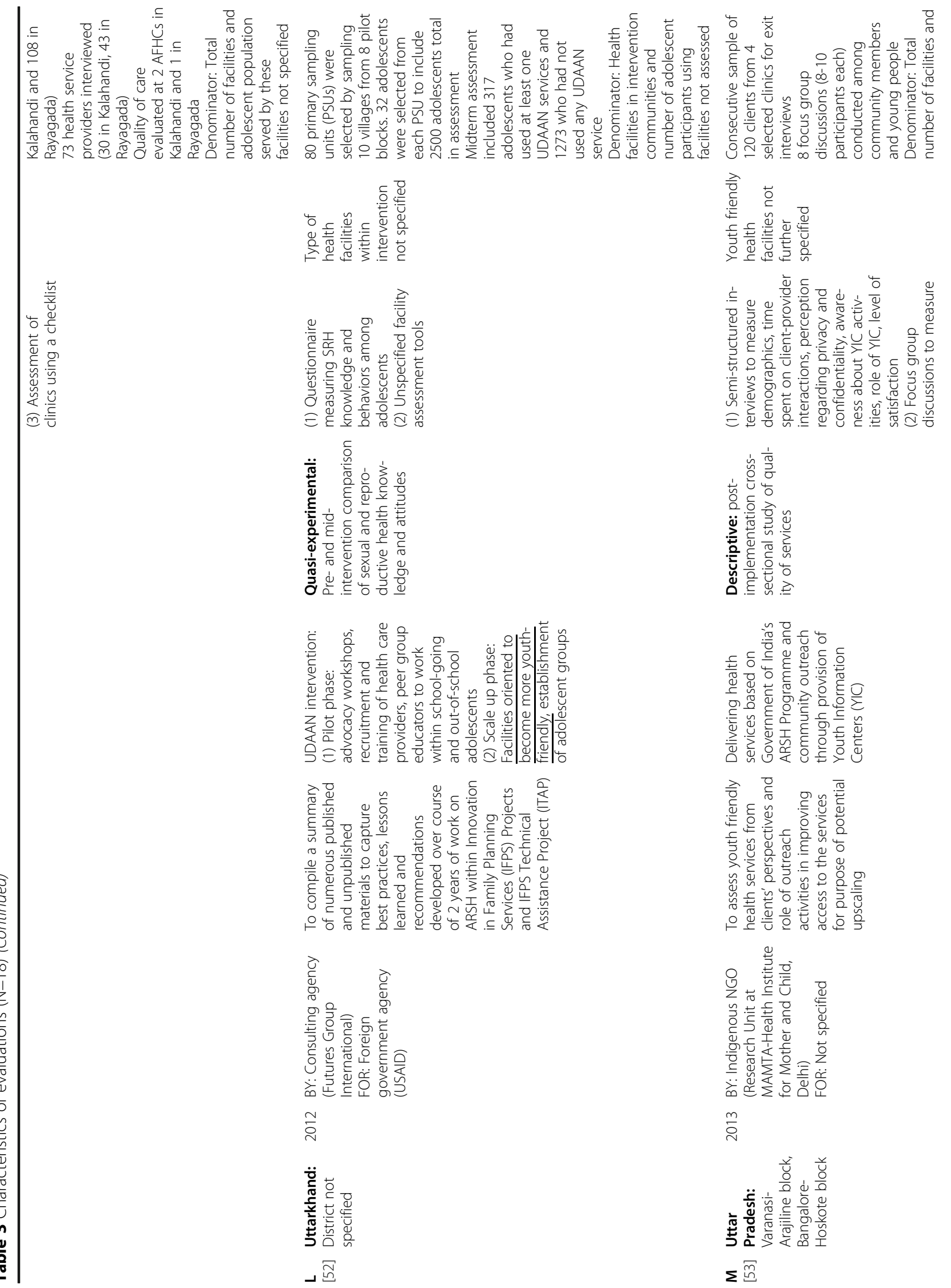




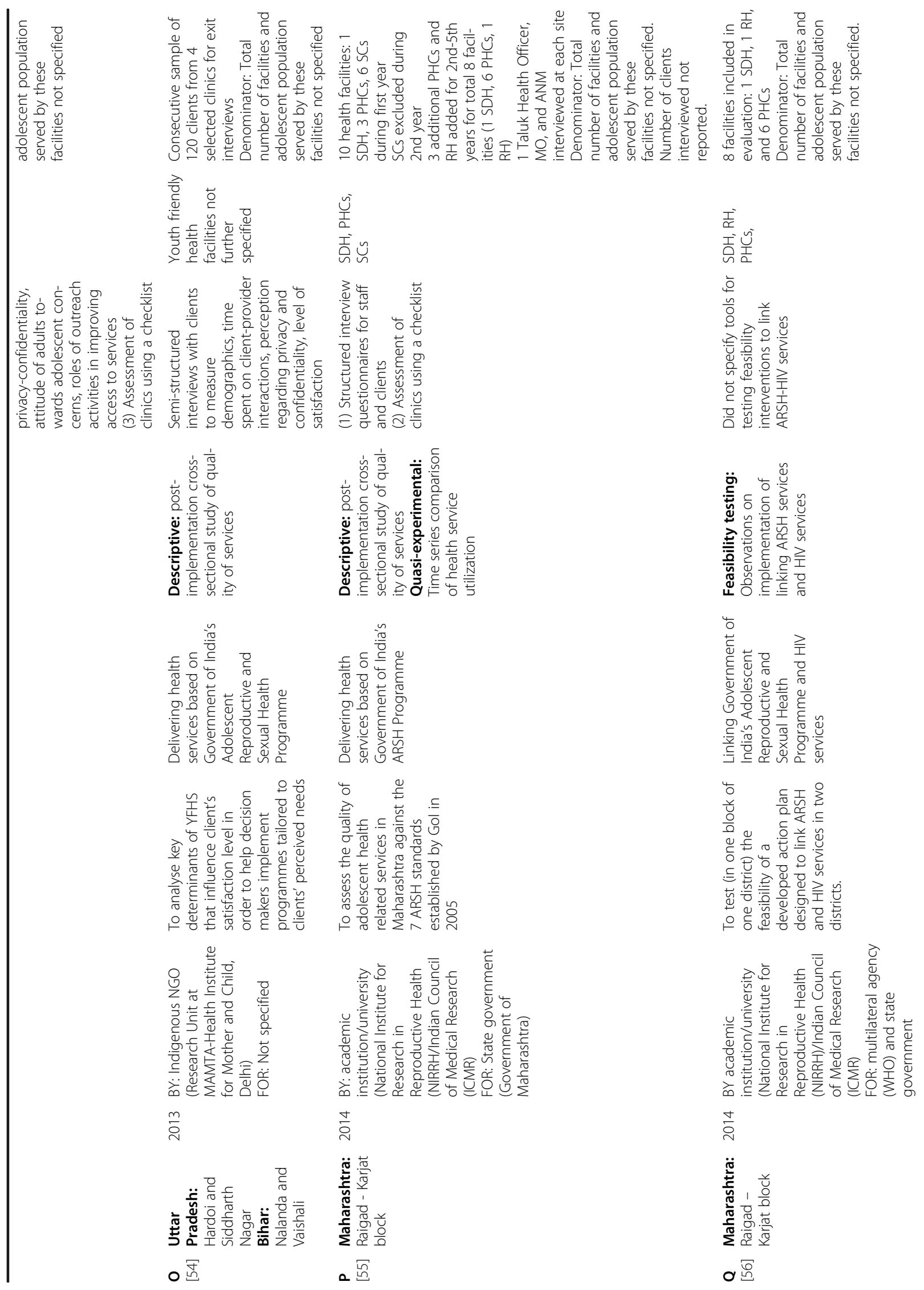



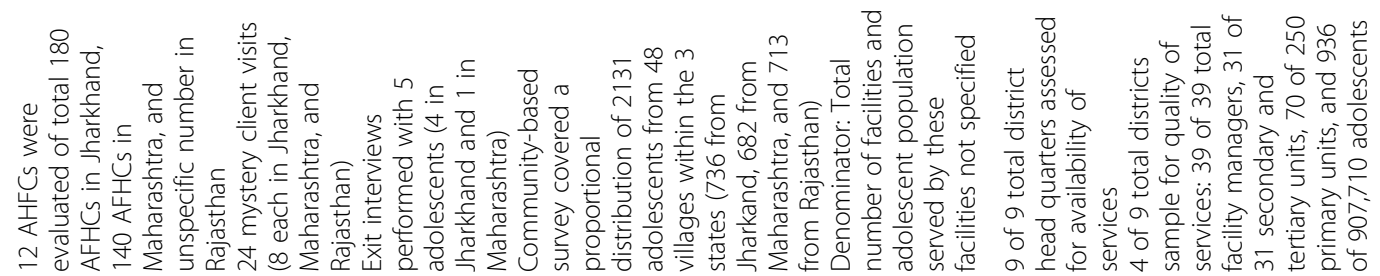

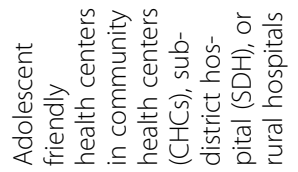

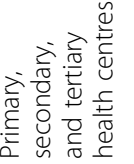

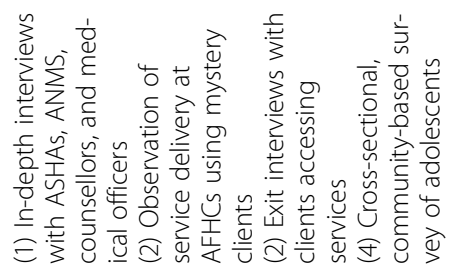
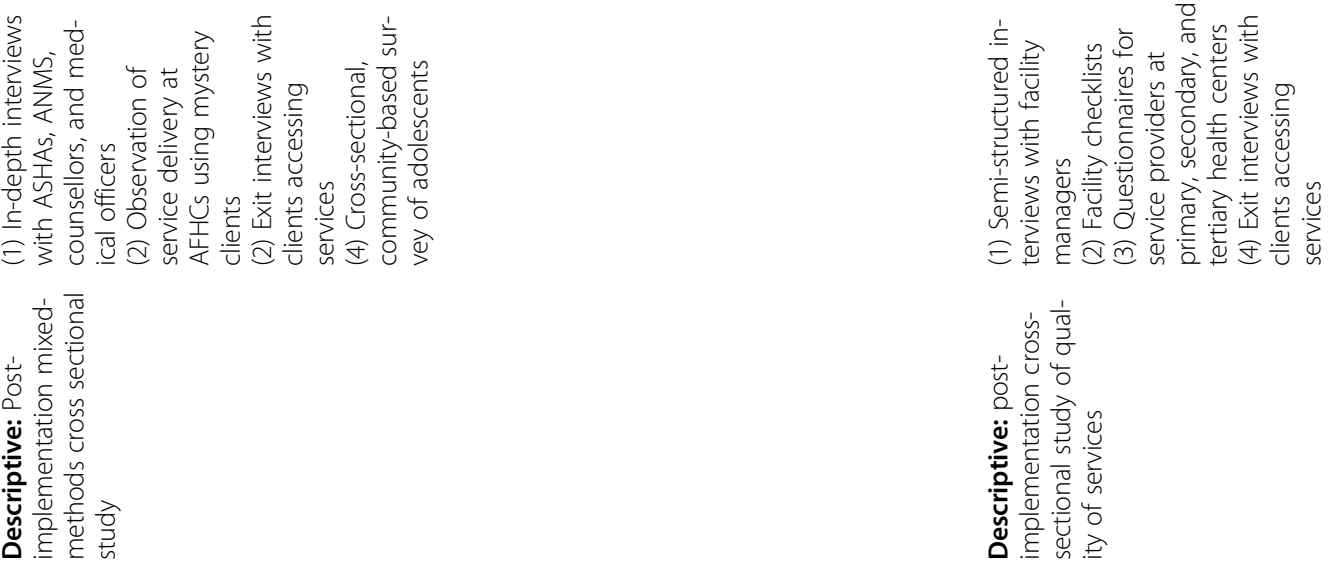

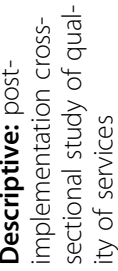

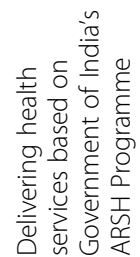

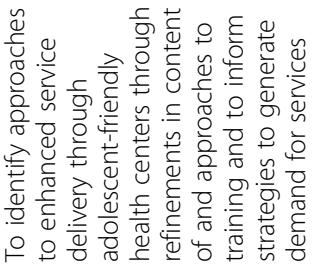

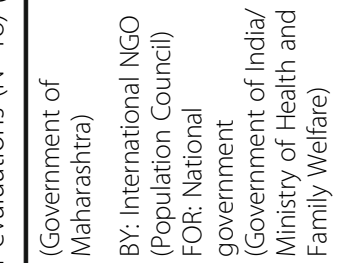

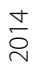

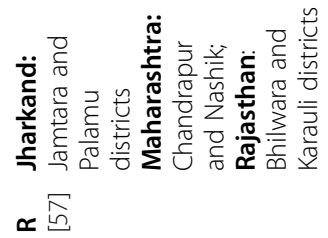

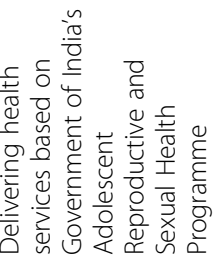

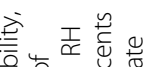

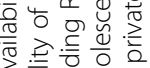

夜

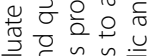

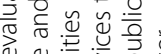

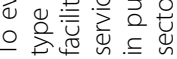

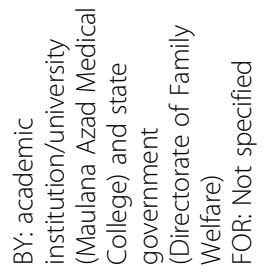

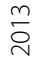

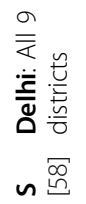




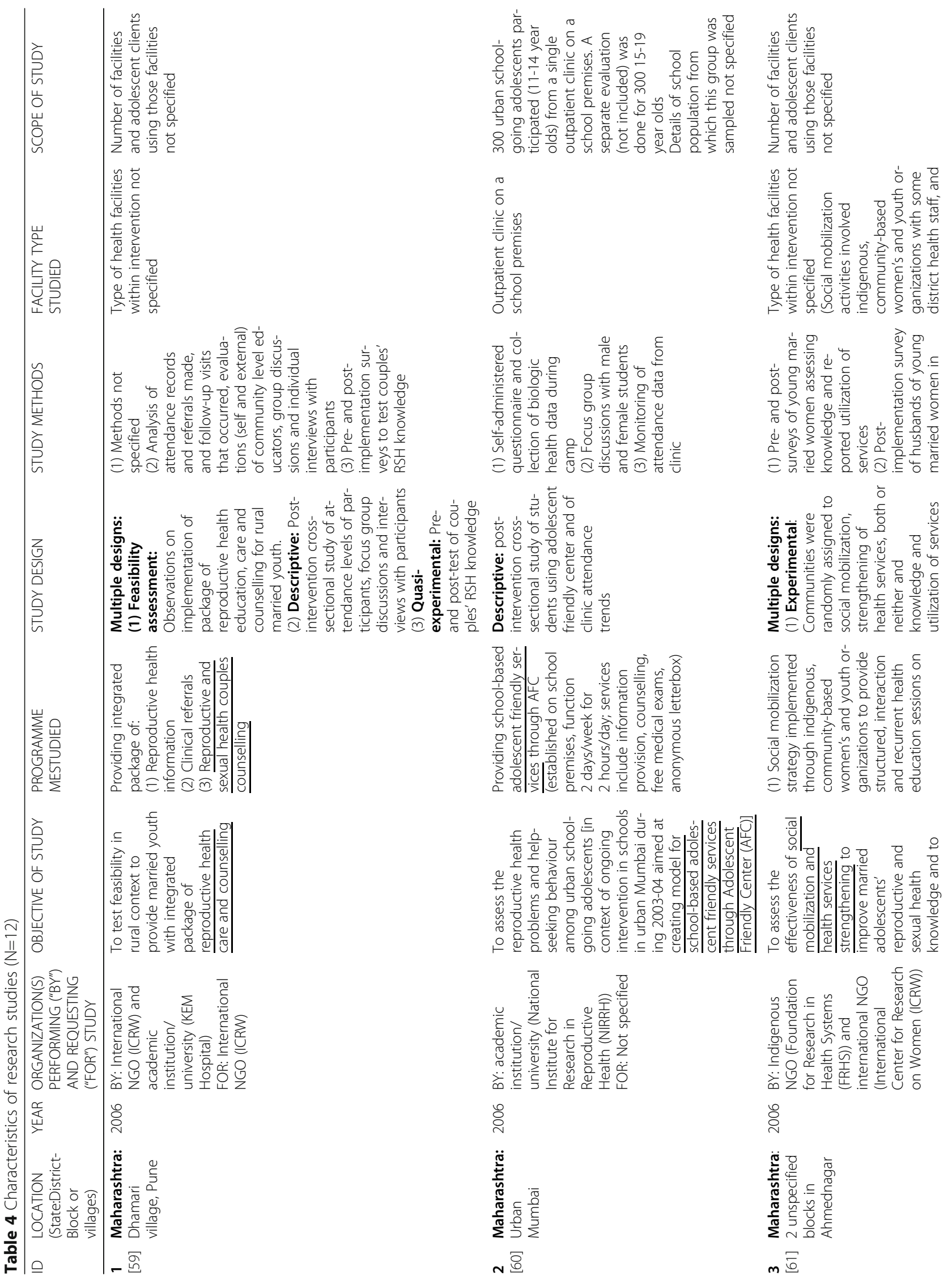



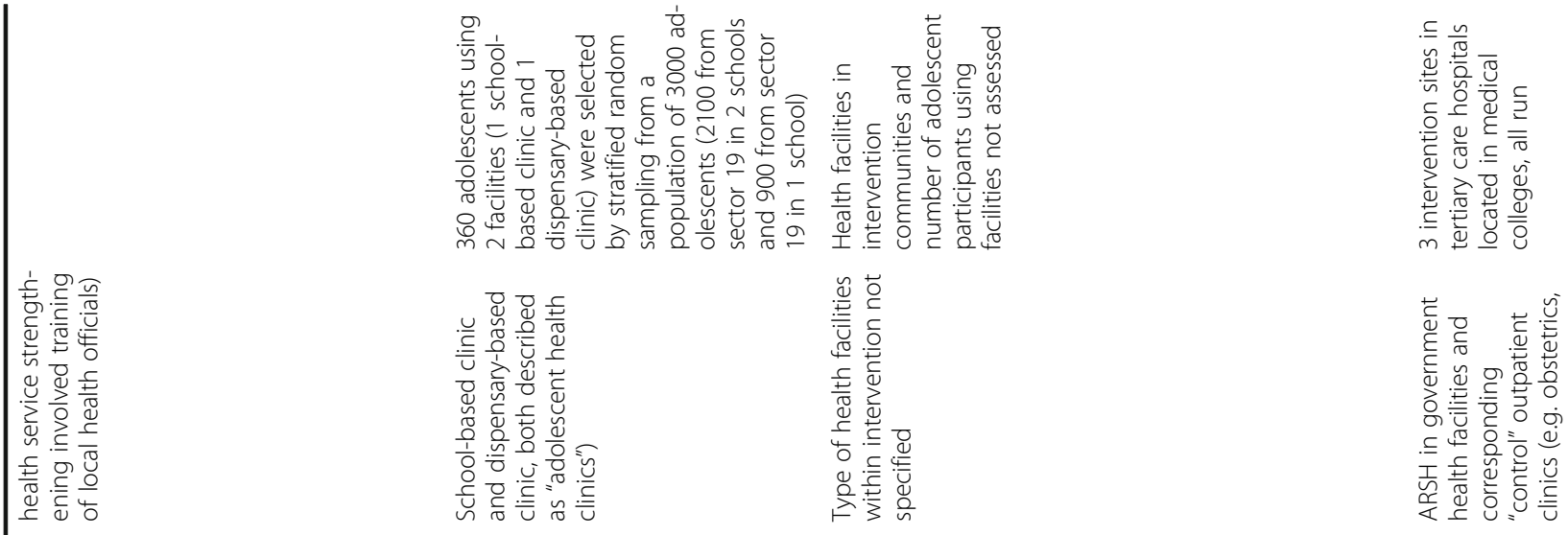

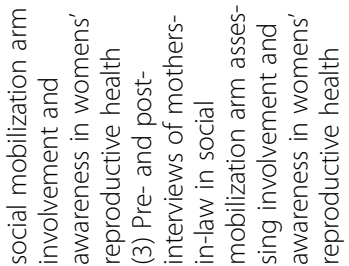

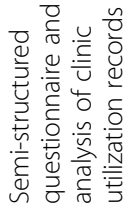

岕岕完

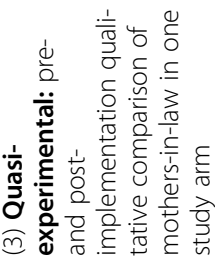

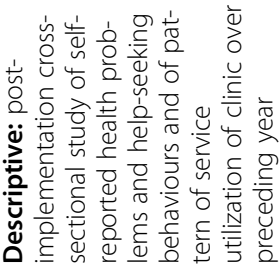

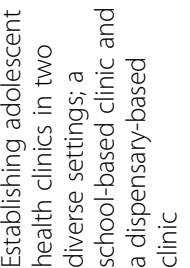

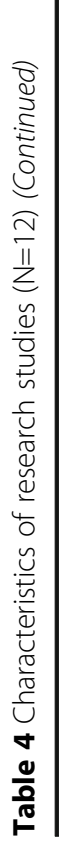

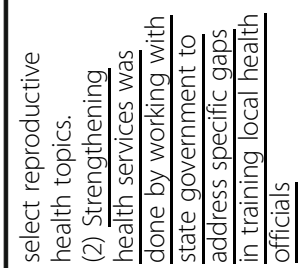

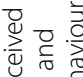

है है

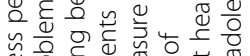

ڤै

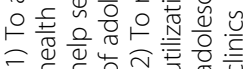

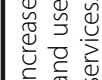

ริำ

崩 $\frac{0}{\frac{0}{c}}$

至毝劳

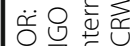

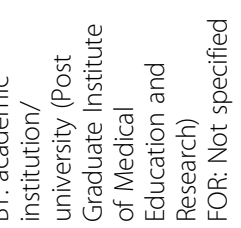

吕

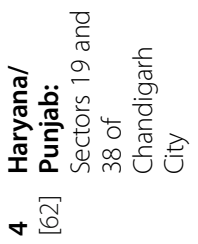

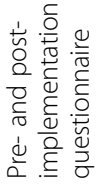
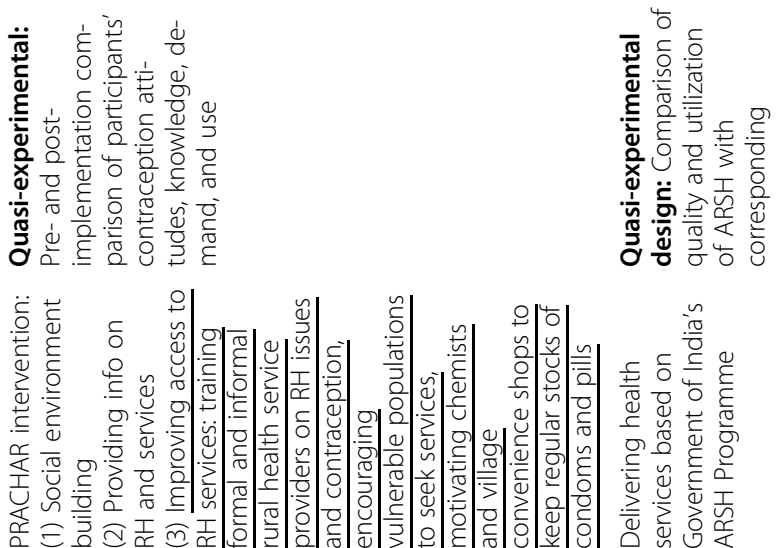

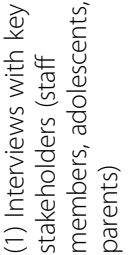

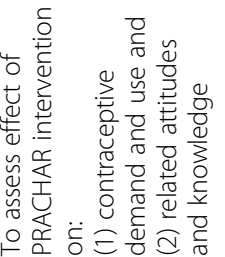

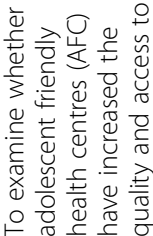

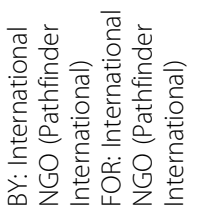

$\infty$

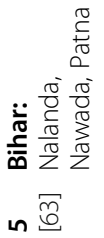

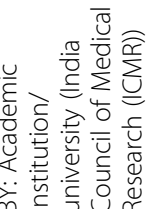

ஓे

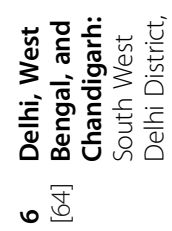




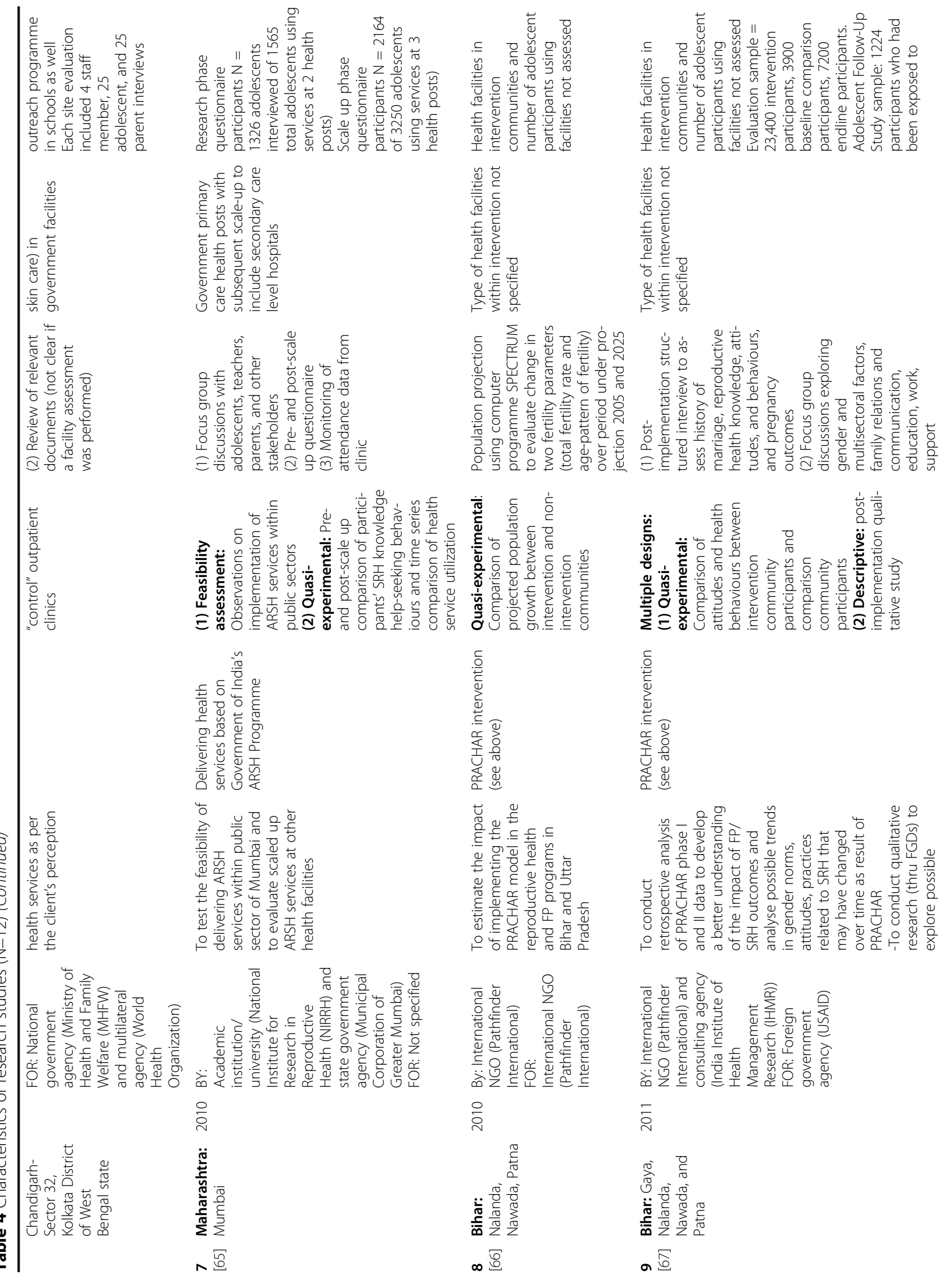




\begin{tabular}{|c|c|c|c|}
\hline \multirow[t]{5}{*}{ 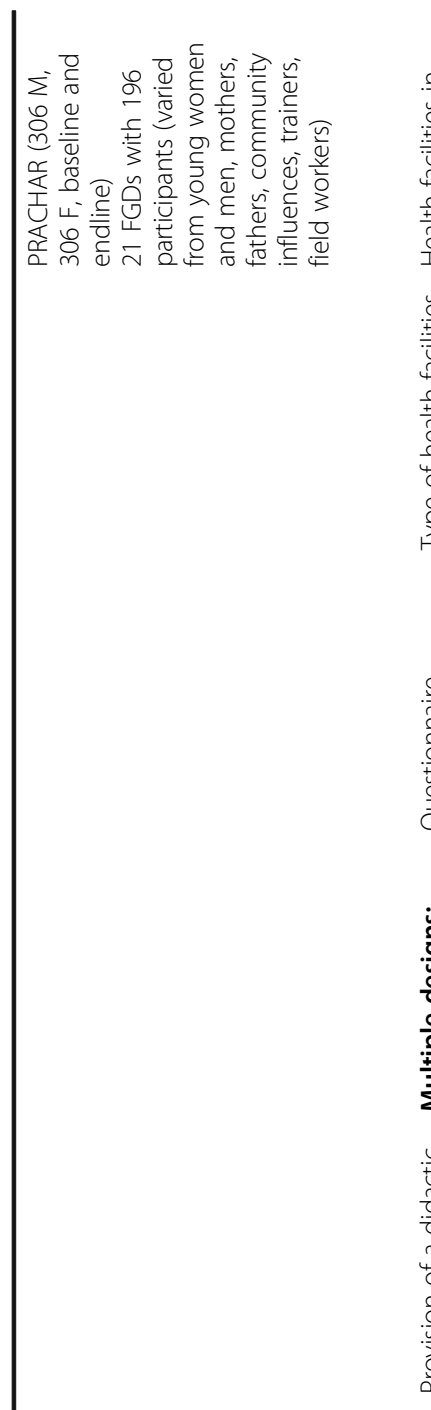 } & 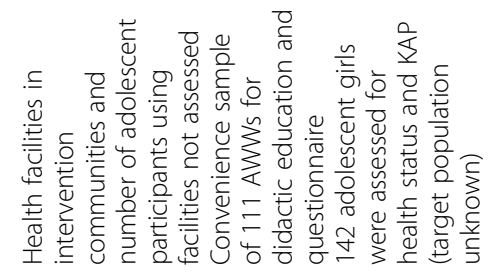 & 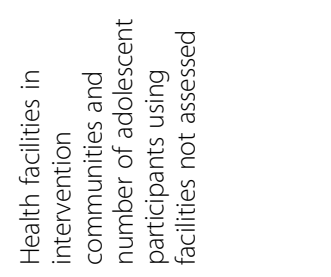 & 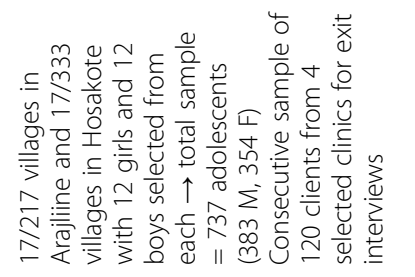 \\
\hline & 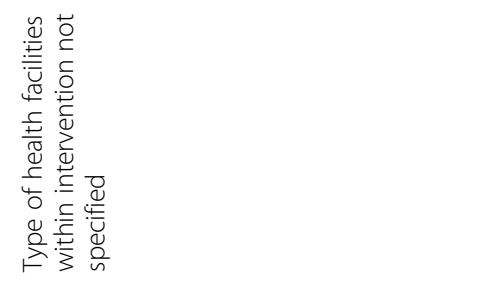 & 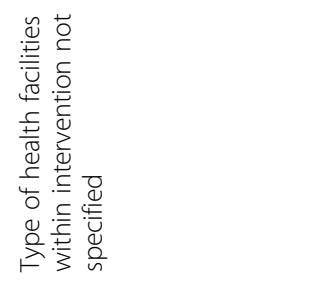 & 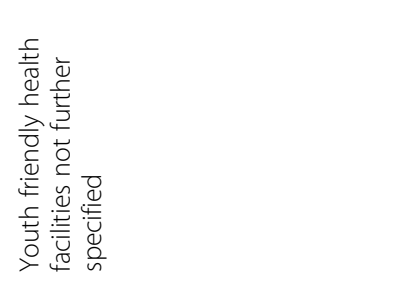 \\
\hline & 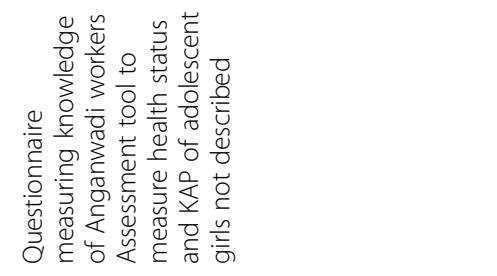 & 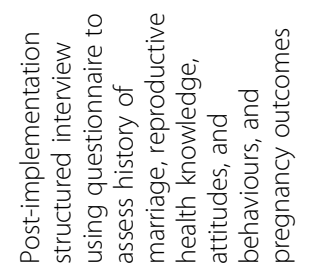 & 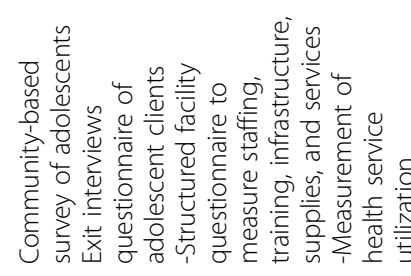 \\
\hline & 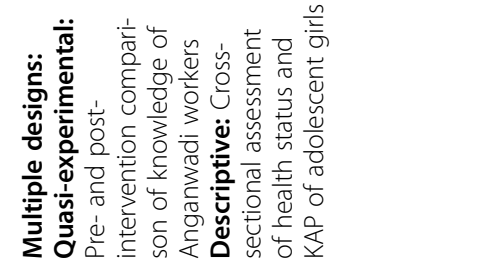 & 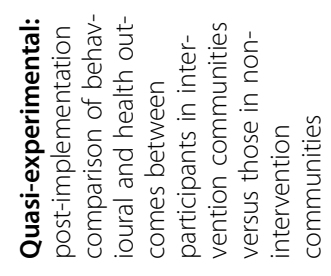 & 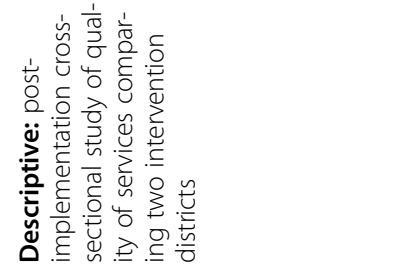 \\
\hline & 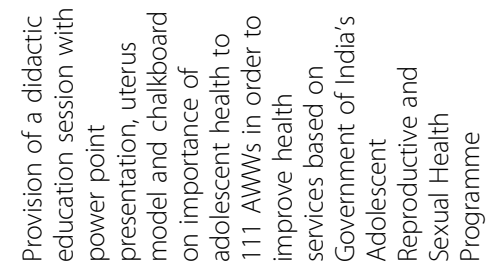 & 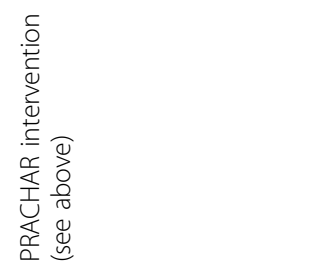 & 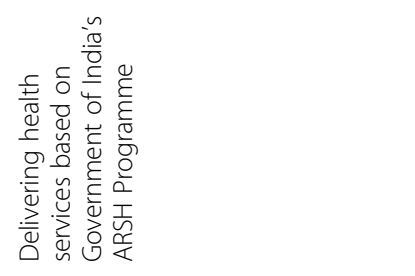 \\
\hline \multirow[t]{4}{*}{ 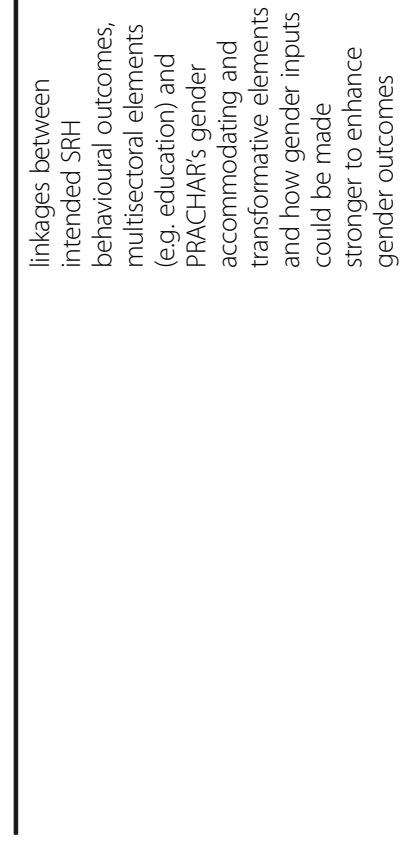 } & 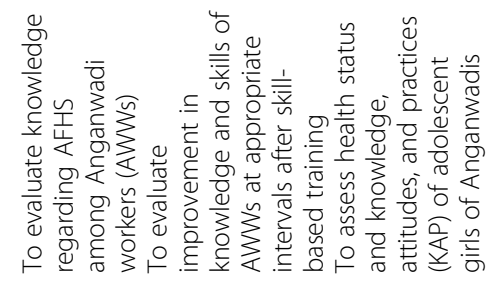 & 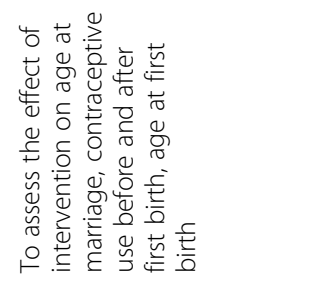 & 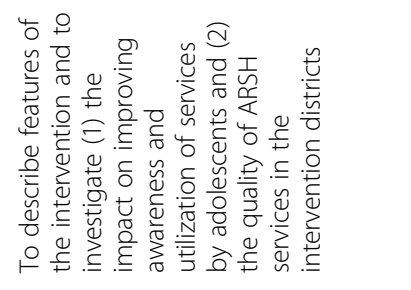 \\
\hline & 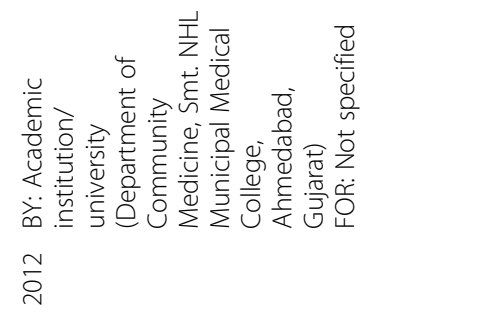 & 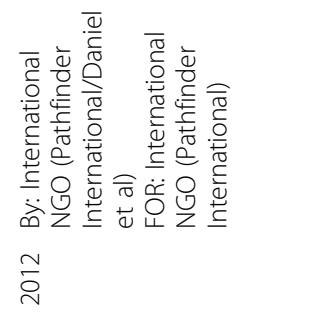 & 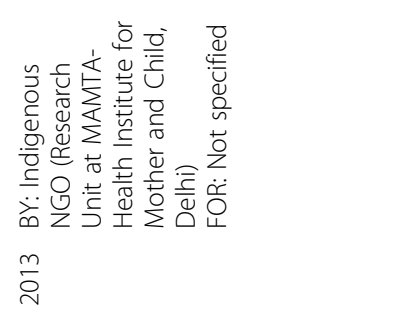 \\
\hline & 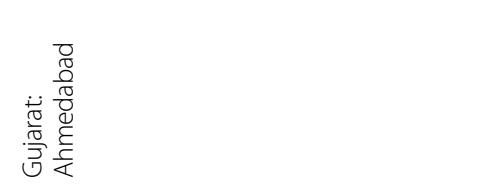 & 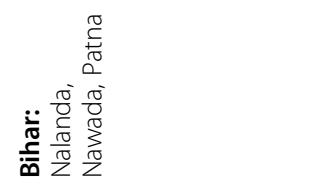 & 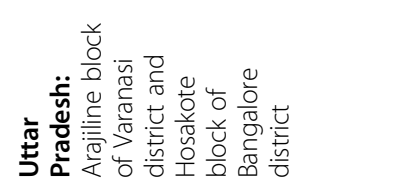 \\
\hline & 오용 & $=$ 鿖 & $\simeq \stackrel{2}{\Sigma}$ \\
\hline
\end{tabular}


Table 5 Main findings of evaluations ( $\mathrm{N}=18)$

\begin{tabular}{|c|c|c|c|}
\hline \multirow[b]{2}{*}{ ID } & \multicolumn{3}{|c|}{ Findings from the evaluations of: } \\
\hline & Design & Implementation & $\begin{array}{l}\text { Outputs (quality and } \\
\text { coverage) }\end{array}$ \\
\hline Eg. & $\begin{array}{l}\text { Project goal } \\
\text { Project objectives } \\
\text { Framework of design } \\
\text { Key approaches and } \\
\text { strategies } \\
\text { Rationale or basis } \\
\text { Key actors }\end{array}$ & $\begin{array}{l}\text { Implementation plan } \\
\text { Activities undertaken } \\
\text { Key influences } \\
\text { Monitoring plan } \\
\text { Use of monitoring } \\
\text { information } \\
\text { Mid-course } \\
\text { adaptations/changes }\end{array}$ & $\begin{array}{l}\text { Pre-inputs: Training } \\
\text { material, training of } \\
\text { trainers, clinical } \\
\text { monitoring (CM), CM } \\
\text { training, supportive } \\
\text { supervision (SS) } \\
\text { material, SS training } \\
\text { Inputs: Training of } \\
\text { health service } \\
\text { providers, making } \\
\text { facilities AFHS, } \\
\text { problem solving, SS } \\
\text { Outputs: Improved } \\
\text { quality of services } \\
\text { Outcomes: Improved } \\
\text { use of services }\end{array}$ \\
\hline
\end{tabular}

Better Life Options participants were more likely to have received antenatal care during pregnancy (91\% vs. $64 \%)$, received tetanus toxoid immunization during pregnancy (91\% vs. 62), delivered in health facility $(50 \%$ vs. $36 \%)$, received post-natal care $(57 \%$ vs. $39 \%$ ), and currently be using contraception (36\% vs. $27 \%$ ) Children of participants

12 months or older more likely to have received complete primary immunizations (63\% vs. $32 \%$ ) Better Life Options participants were more likely to report having given child oral rehydration salts during diarrhoea (42\% vs. $12 \%)$

Statistically significant $(p<0.01)$ percent change $(\% \Delta)$ in knowledge of modern methods of contraception (male) female sterilization $37.6 \% \Delta$, condoms $34.6 \% \Delta$ intrauterine device $25.0 \% \Delta$, desire for less than 3 children $13.1 \% \Delta$, knowledge about need for 3 antenatal care checkups $\% \Delta$ Statistically significant $(p<0.01)$ increases in
Health outcomes Comments

Eg. nutritional status, early pregnancy and pregnancy related mortality and morbidity, STIs and HIV

Other evaluation dimensions: community support and adolescent demand, planning and management, institutionalisation, cost

Better Life Options Other social participants had lower outcomes including mean number of children (1.73 vs. 1.98$)$ age at marriage, level Better Life Options of education participants had lower were also were also rates of child deaths evaluated ( $R R=0.88)$
Statistically significant $(p<0.01)$ reduction in proportion of

participants with anemia

(Hemoglobin $<10$ grams) from $86 \%$ to 20\% among 10-14 years and $86 \%$ to $36 \%$ among $15-19$ years Mean Hemoglobin level improved $(9.0$ grams/dL to 11.1 grams/dL in 10-14 years, $9.0 \mathrm{grams} / \mathrm{dL}$ to 10.7 grams/dL in 1519 years) 
Table 5 Main findings of evaluations ( $\mathrm{N}=18)$ (Continued)

knowledge for each of

4 modes of HIV

transmission (sharing

needles $39.8 \% \Delta$,

unprotected sex

$30.1 \% \Delta$, mother to

child transmission

$32.3 \% \Delta$, blood

transfusion with

infected blood

35.0)\% $\Delta$

Evaluation identified Difference in quality

programme

scores between ARSH

implementation,

noting that ARSH-

and other clinics for

related supplies were

found to be available,

each standard

(statistical significance

ing distributed to

1. Health facilities

provide the specific

package of health

services that

adolescents need: $65 \%$

in ARSH versus $22 \%$ in

other

2. Health facilities

deliver effective

services to

adolescents: 78\%

versus 39\%

3. Adolescents find the

environment at health

facilities conducive to

seeking treatment:

$86 \%$ versus $33 \%$

4. Service providers are

sensitive to adolescent

needs and are

motivated to work

with them: $94 \%$ versus

$59 \%$

5. An enabling

environment for

adolescents to seek

services exists in

community: $63 \%$

versus $12 \%$

6. Adolescents are well

informed about health

services: $44 \%$ versus

$1 \%$

7. Management

systems are in place to

improve/sustain the

quality of health

services: $45 \%$ versus

$13 \%$

No apparent

difference in

performances of PHCs

vs. SCs

Most intervention sites

progressing well

towards meeting the

standards

D

Awareness of AFHS 8x

higher in intervention

area than comparison 
Table 5 Main findings of evaluations ( $\mathrm{N}=18)$ (Continued)

\begin{tabular}{|c|c|c|c|}
\hline & & $\begin{array}{l}\text { villages (68\% versus } \\
8 \%)^{\circ} \\
\text { Use of government } \\
\text { health facilities was } \\
\text { higher in intervention } \\
\text { than comparison } \\
\text { villages (55\% } \\
\text { versus37\%) } \\
\text { Denial of } \\
\text { contraceptive services } \\
\text { was perceived by } \\
\text { majority of } \\
\text { adolescents in both } \\
\text { intervention and } \\
\text { comparison villages } \\
\text { More adolescents in } \\
\text { intervention villages } \\
\text { understood } \\
\text { explanations of health } \\
\text { problems than in } \\
\text { comparison ( } 83 \% \\
\text { versus } 42 \%)^{\circ} \\
\text { No major differences } \\
\text { between groups in } \\
\text { acceptability and } \\
\text { availability of condoms }\end{array}$ & \\
\hline$E$ & $\begin{array}{l}\text { Some centres were } \\
\text { non-functional due to } \\
\text { transfer of MO who } \\
\text { was oriented about } \\
\text { centre and lack of hu- } \\
\text { man resources } \\
\text { Major challenges to } \\
\text { monitoring exist }\end{array}$ & $\begin{array}{l}\text { Utilization data } \\
\text { (average number of } \\
\text { adolescent patients/ } \\
\text { month) showed } \\
\text { minimal utilization. } \\
\text { Where records } \\
\text { available, average } 250 \\
\text { adolescent clients/ } \\
\text { month. } \\
\text { Focus groups revealed } \\
\text { that adolescent boys } \\
\text { and girls are generally } \\
\text { unaware of ARSH } \\
\text { centres and/or } \\
\text { services. Use of } \\
\text { services related to RSH } \\
\text { problems is limited } \\
\text { due to lack of } \\
\text { awareness and } \\
\text { knowledge }\end{array}$ & $\begin{array}{l}\text { Quality of health } \\
\text { services based on } \\
\text { provider report, not } \\
\text { direct observation, } \\
\text { and scoring } \\
\text { performed by } \\
\text { evaluation team }\end{array}$ \\
\hline$F$ & $\begin{array}{l}\text { Only } 1 \text { facility (SDH) } \\
\text { was "designated" } \\
\text { AFHS at time of } \\
\text { assessment }\end{array}$ & $\begin{array}{l}\text { Proportion of } 7 \\
\text { standards of ASRH } \\
\text { services implemented } \\
\text { at each facility ranged } \\
\text { from } 19 \% \text { to } 42 \% \\
\text { Single facility that had } \\
\text { been designated AFHS } \\
\text { (SDH in Karjat) scored } \\
31 \% \\
\text { Most broadly } \\
\text { implemented standard } \\
\text { ( } 57 \% \text { of facilities met } \\
\text { standard) was } \\
\text { standard 4: "Service } \\
\text { providers are sensitive } \\
\text { to adolescent needs } \\
\text { and motivated to } \\
\text { work with them." } \\
\text { Least implemented } \\
\text { standard (1\% of } \\
\text { facilities met standard) }\end{array}$ & $\begin{array}{l}\text { Positive feasibility of } \\
\text { using quality } \\
\text { assessment tools } \\
\text { Comment that focus } \\
\text { group discussions are } \\
\text { needed to gather } \\
\text { better inputs for } \\
\text { standards } V \text { and } V I\end{array}$ \\
\hline
\end{tabular}


Table 5 Main findings of evaluations ( $\mathrm{N}=18)$ (Continued)

was standard 6

("Adolescents are wellinformed about health services.")

G

$83 \%$ of clinics had been functional for less than one year
H
$42 \%$ maintained audio and visual privacy $58 \%$ had displayed boards and 25\% had adequate signage No ARSH facilities were found to have at least 100 condoms or at least 10 cycles of Oral Contraceptive Pills available, 83\% had Emergency

Contraceptive Pills available

$67 \%$ had access to

ARSH guidelines

Utilization of services

low: $14.5 \%$ of

adolescents

interviewed had used

clinic in past

6 months)

Few providers felt adequately trained

53,137 adolescents (40\% male, 60\%

female) accessed services provided by

73 clinics

-Scope of services included contraceptive choices, handling concerns related to menstruation and gender-based violence, improving life skills, providing antenatal services, treatment of Reproductive Tract Infections/Sexually Transmitted

Infections

Access and quality of services were quite

limited (report did not provide data to support this)

Adolescent health care available in $85.4 \%$ of SCs in 7 different states

School health programmes in $77 \%$ of PHCs and related facilities in different states

ASHA participation in sensitizing adolescent girls was found to be unsatisfactory (Data not provided to support this) 
Table 5 Main findings of evaluations $(\mathrm{N}=18)$ (Continued)

J

If comprehensive

intervention is

discontinued, there is

an initial decline in

contraceptive use in

both groups after

activities end, then

stabilizes at higher

level than pre-

intervention

Longer duration of

comprehensive

intervention was

associated with

greater increase in

contraceptive use (a

more modest effect

demonstrated over

shorter (2-3years)

period of time

Joint exposure of

young married

couples to PRACHAR

communications is

more effective than

exposure to men

alone

PRACHAR

interventions led to

increased

contraceptive use

among all

socioeconomic and

education groups, but

highest impact in

most disadvantaged

AWW and ASHA

stakeholders have

more knowledge

about health

concerns/programnes

meant for adolescents

than did teacher and

Panchayati Raj

Institution members

Quality of services

most adequate in

relation to facility

measure (separate

room, exam table,

display boards,

records/registers,

weighing scale) and

supply measures

(condoms, Oral

Contraceptive Pills,

Emergency

Contraception, etc.)

Information Education

Communication

materials and outreach

services, co-curricular

education activities are

lacking
L

Scale-up included

changes based on

findings from
Low SRH knowledge

in adolescent

community
Improved attitudes

and behaviours

related to 
Table 5 Main findings of evaluations ( $\mathrm{N}=18)$ (Continued)

\author{
evaluation of pilot \\ intervention, including \\ the addition of new \\ service delivery points, \\ shift in monitoring \\ responsibilities, \\ improvements in \\ efficiency of services
}

reproductive and

sexual health

including decrease on

preference for male

child from 39.9\% to

$25.7 \%$ ( $p<0.01)$,

increased awareness

of legal minimum age

of marriage for girls

from $68.2 \%$ to $85.4 \%$

$(p<0.01)$, and

increased use of

sanitary pads

increased from 30.6\%

to $52.7 \%(p<0.01)$
Majority (90\%) of clients aware that YFHS provide services to young men and women separately on specific day/time $66 \%$ of clients visited YFHS to seek treatment for 3 key problems

(menstruation, general illness, swelling/itching of genitals)

Privacy not consistently ensured according to clients

$32 \%$ of interviewed clients reported satisfaction with AFHS Satisfaction was positively associated with female gender, higher education status, Hindu religion Multivariate model showed greater satisfaction associated with parental support (odds ratio $=4.4$ ) much lower satisfaction associated with fear of privacy disclosure to parents (odds ration $=0.08$ ) this factor was more important than parental attitudes

Client satisfaction did not vary by appropriateness of time given by provider, clients' belief regarding confidentiality of information, provision of information request

P
Raw quality scores showed steady improvement with average score of $83 \%$ across all 8 health 
Table 5 Main findings of evaluations $(\mathrm{N}=18)$ (Continued)

\begin{tabular}{|c|c|c|c|c|c|}
\hline & & & $\begin{array}{l}\text { facilities in } 5 \text { th year of } \\
\text { evaluation and } 79 \% \\
\text { across } 12 \text { sub-centres. } \\
\text { No statistical analysis } \\
\text { of change in scores } \\
\text { over time. } \\
\text { Persistently low } \\
\text { performance of } \\
\text { standard II } \\
\text { (effectiveness of health } \\
\text { facilities, including } \\
\text { equipment and } \\
\text { supplies) }\end{array}$ & & \\
\hline$Q$ & $\begin{array}{l}\text { Situation analysis } \\
\text { informed } \\
\text { development of the } \\
\text { following } \\
\text { interventions as a } \\
\text { block action plan: } \\
\text { (1) Refresher trainings } \\
\text { for providers (2) } \\
\text { Linkages with schools } \\
\text { ad community } \\
\text { organizations (3) } \\
\text { Standard operating } \\
\text { procedures and } \\
\text { management } \\
\text { information systems } \\
\text { (4) Demand } \\
\text { generation through } \\
\text { collaboration with } \\
\text { education } \\
\text { department (5) } \\
\text { Mobile helpline } \\
\text { service (6) Quality } \\
\text { assessment } \\
\text { programme } \\
\text { evaluation at the end } \\
\text { of each year to be } \\
\text { performed by } \\
\text { external evaluators- }\end{array}$ & $\begin{array}{l}\text { Feasibility assessment } \\
\text { of block action plan } \\
\text { found that: (1) } \\
\text { Adolescents will not } \\
\text { come to clinic on a } \\
\text { particular ARSH day, } \\
\text { so clinic schedule } \\
\text { shifted to "anytime } \\
\text { approach" in the block } \\
\text { (2) Medical camps for } \\
\text { adolescents helped } \\
\text { strengthen linkages } \\
\text { with schools/colleges, } \\
\text { parents, and teachers } \\
\text { and have facilitated } \\
\text { demand generated (3) } \\
\text { Linkages with NGOs } \\
\text { helped created } \\
\text { awareness of ARSH } \\
\text { services (4) Proactive } \\
\text { involvement of } \\
\text { education system and } \\
\text { clear guidelines are } \\
\text { essential (5) Referrals } \\
\text { within the block are } \\
\text { not helpful since } \\
\text { quality at sub-district } \\
\text { hospitals are not } \\
\text { superior } \\
\text { (6) Interventions with } \\
\text { limited scope were } \\
\text { peer volunteers, } \\
\text { mobile line service, } \\
\text { and an adolescent } \\
\text { health committee } \\
\text { (7) Clear cut guidelines } \\
\text { on ARSH exist from } \\
\text { Government of India, } \\
\text { but no departments } \\
\text { except health sector } \\
\text { have specific policies } \\
\text { for roles and } \\
\text { responsibilities related } \\
\text { to adolescents }\end{array}$ & $\begin{array}{l}\text { Findings of quality } \\
\text { assessment } \\
\text { programme } \\
\text { reported in separate } \\
\text { evaluation document } \\
\text { (43) }\end{array}$ & & \\
\hline $\mathbf{R}$ & & & $\begin{array}{l}\text { Most health care } \\
\text { providers had } \\
\text { undergone some } \\
\text { training or } \\
\text { sensitisation on SRH } \\
\text { issues relevant to } \\
\text { adolescents - some } \\
\text { within context of } \\
\text { general training and }\end{array}$ & $\begin{array}{l}<50 \% \text { of surveyed } \\
\text { men and }<66 \% \text { of } \\
\text { surveyed women who } \\
\text { experienced an SRH } \\
\text { problem had sought } \\
\text { advice and/or } \\
\text { treatment, fewer (33\%) } \\
\text { for mental health } \\
\text { concerns. Most sought }\end{array}$ & $\begin{array}{l}\text { Report also } \\
\text { summarizes the } \\
\text { perceived health } \\
\text { problems among } \\
\text { adolescents surveyed } \\
\text { as well as their } \\
\text { preferences about } \\
\text { health care providers } \\
\text { and facilities }\end{array}$ \\
\hline
\end{tabular}


Table 5 Main findings of evaluations ( $\mathrm{N}=18)$ (Continued)

\begin{tabular}{|c|c|c|}
\hline & $\begin{array}{l}\text { others through special } \\
\text { training programmes } \\
\text { ASHA and ANM } \\
\text { training more often } \\
\text { focused on "safer } \\
\text { issues" like nutrition } \\
\text { and menstrual } \\
\text { hygiene while } \\
\text { counsellors and MOs } \\
\text { also received training } \\
\text { on sexual relations, } \\
\text { infection, pregnancy, } \\
\text { and abortion. } \\
\text { Fewer training } \\
\text { experiences with } \\
\text { privacy, confidentiality, } \\
\text { non-judgemental } \\
\text { interaction, promotion } \\
\text { of informed choice, } \\
\text { and communication } \\
\text { skills } \\
\text { "Cascade approach" to } \\
\text { training reaches large } \\
\text { numbers, but not } \\
\text { successful in building } \\
\text { capacity on intractable } \\
\text { aspects of service } \\
\text { provision like building } \\
\text { communication skills } \\
\text { and overcoming } \\
\text { discomfort in talking } \\
\text { about SRH issues } \\
\text { Gendered responses } \\
\text { regarding what } \\
\text { information } \\
\text { adolescents should } \\
\text { receive, most believed } \\
\text { that information } \\
\text { provision to girls } \\
\text { should be mothers } \\
\text { and female providers } \\
\text { like ASHAs and ANMs } \\
\text { while boys should get } \\
\text { information from } \\
\text { other males (MOs, } \\
\text { counsellors, etc.) } \\
\text { Providers generally } \\
\text { observe that } \\
\text { adolescents and youth } \\
\text { do not access SRHS } \\
\text { available at } \\
\text { community level or at } \\
\text { AFHCs at facility levels } \\
\text { Based on exit } \\
\text { interviews and mystery } \\
\text { clients, suitability of } \\
\text { services was mixed } \\
\text { with most commonly } \\
\text { cited complaint being } \\
\text { lack of privacy }\end{array}$ & $\begin{array}{l}\text { medical officers in } \\
\text { government or private } \\
\text { facilities. } \\
\text { Adolescents reported } \\
\text { limited interaction } \\
\text { with frontline and } \\
\text { community HCPs } \\
\text { (ANMs, ASHAs, and } \\
\text { AWWs) } \\
\text { Awareness of AFHCs } \\
\text { was low among } \\
\text { adolescents (5\% of } \\
\text { young men and } 8 \% \text { of } \\
\text { young women } \\
\text { surveyed were aware } \\
\text { of services), <1\% had } \\
\text { ever sought services }\end{array}$ \\
\hline$S$ & $\begin{array}{l}\text { Data on health } \\
\text { facilities providing } \\
\text { ARSH services is sparse } \\
\text { and only covers public } \\
\text { facilities. } \\
\text { There has been } \\
\text { insufficient training of }\end{array}$ & $\begin{array}{l}\text { Low awareness of } \\
\text { ARHS problems and } \\
\text { availability of service } \\
\text { among adolescents in } \\
\text { community }\end{array}$ \\
\hline
\end{tabular}


Table 5 Main findings of evaluations ( $N=18)$ (Continued)

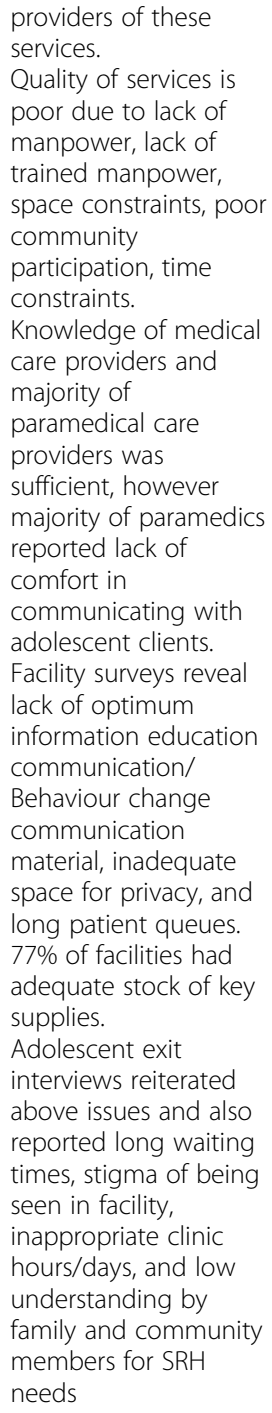

multilateral agency $(\mathrm{H})$. We found many partnerships between NGOs and state government agencies and also that most publications had multiple authors and contributors from different disciplines. The majority of reports/ articles (A,B,D,E,F,G,I,L,P,Q,R; 1,3,6,7,9) involved a research/evaluation team that was external to the implementing agency.

\section{For what purpose have these evaluations/studies been conducted?}

Nearly all reports contained clearly defined objectives, often with multiple components. Common objectives were to assess the quality of health services provided to adolescents (process: C,E,F,G,H,I,K,L,M,N,O,R,S; 6,10,12), to assess changes in the utilization of health services by adolescents (outputs: $D, E, H, \mathrm{~K} ; 2,3,4,12$ ), and to measure $\mathrm{RSH}$ knowledge of adolescents exposed to a programme (outcomes: B,J,K,L; 3,5,9,10). Few studies/evaluations aimed to assess behavioural outcomes such as condom or contraception use (outcomes: $A, J ; 4,5$ ) or health outcomes such as age at first birth associated with programme exposure (results/impact: 9,11). One large multi-component project called PRACHAR was evaluated in multiple studies and reports which examined various outcomes including age at first birth, birth spacing, and haemoglobin levels of participants $(J ; 5,8,9,11)$. Only the PRACHAR project evaluated the impact on community or population level outcomes such as age at marriage and first birth.

\section{What evaluation/study designs and methods have been used?}

We observed a variety of designs used to perform these studies/evaluations, falling broadly into categories of descriptive, quasi-experimental, feasibility assessment, 
Table 6 Main findings of research studies $(N=12)$

\begin{tabular}{|c|c|c|c|c|c|}
\hline \multicolumn{6}{|c|}{ Findings from the studies of: } \\
\hline ID & Design & Implementation & $\begin{array}{l}\text { Outputs (quality and } \\
\text { coverage) }\end{array}$ & $\begin{array}{l}\text { Health behaviour } \\
\text { outcomes }\end{array}$ & Comments \\
\hline 1 & $\begin{array}{l}\text { Evaluation of project } \\
\text { design: } \\
\text { Project design of RSH } \\
\text { counselling to married } \\
\text { men and women, } \\
\text { individuals or couples } \\
\text { is feasible } \\
\text { Pre-existing } \\
\text { community } \\
\text { perceptions and } \\
\text { community level } \\
\text { educators (CLE's) } \\
\text { acceptability in } \\
\text { community must be } \\
\text { considered when } \\
\text { choosing a CLE } \\
\text { More than expected } \\
\text { time and effort is } \\
\text { required to train rural } \\
\text { volunteers, prepare } \\
\text { manual for them to } \\
\text { use in field, and test, } \\
\text { modify, and finalize } \\
\text { activities) } \\
\text { Continuous retraining } \\
\text { was critical }\end{array}$ & & $\begin{array}{l}\text { Youth participation } \\
\text { outputs: } \\
89.3 \% \text { attended at least } \\
1 \text { reproductive health } \\
\text { education (RHE) } \\
\text { session } \\
76.2 \% \text { attended } 4 \text { or } \\
\text { more days of RHE } \\
48.2 \% \text { attended all RHE } \\
\text { sessions } \\
\text { Clinical attendance } \\
\text { outputs: } \\
70 \% \text { received clinical } \\
\text { referrals thru RHE } \\
33.3 \% \text { received clinic } \\
\text { referrals through } \\
\text { counselling } \\
29 \% \text { received } \\
\text { counselling referrals } \\
\text { throught RHE } \\
55 \% \text { of those in } \\
\text { counselling were } \\
\text { coming for follow up }\end{array}$ & $\begin{array}{l}\text { Knowledge and } \\
\text { awareness outcomes: } \\
\text { Men's and women's } \\
\text { awareness of various } \\
\text { health issues (including } \\
\text { menstruation, delivery, } \\
\text { contraception, } \\
\text { abortion) increased } \\
\text { overall, but not for } \\
\text { other issues covered in } \\
\text { sessions } \\
\text { If individual did not } \\
\text { attend a session, their } \\
\text { awareness increased if } \\
\text { partner did } \\
\text { Qualitative data } \\
\text { suggests couples } \\
\text { discussed RSH issues } \\
\text { outside of sessions }\end{array}$ & \\
\hline 2 & & & $\begin{array}{l}\text { Intervention of school- } \\
\text { based AFHS increased } \\
\text { client attendance from } \\
\text { one year to next ( } 43 \% \\
\text { to } 60 \% \text { among girls, } \\
35 \% \text { to } 42 \% \text { among } \\
\text { boys) }\end{array}$ & $\begin{array}{l}\frac{\text { Biologic measures at }}{\text { One year follow-up (no }} \\
\text { baseline recorded): } \\
93.5 \% \text { of girls were } \\
\text { anemic (mean } \\
\text { haemoglobin } 9.6 \\
\text { grams) } \\
14.8 \% \text { of girls were } \\
\text { below } 5 \text { th percentile } \\
\text { and } 4 \% \text { of girls were } \\
\text { above } 95 \text { th percentile } \\
\text { for weight, mean body } \\
\text { mass index (BMI) } 19.1 \\
82.3 \% \text { of boys were } \\
\text { anaemic (mean } \\
\text { haemoglobin } 10.7 \\
\text { grams) } \\
29.3 \% \text { of boys were } \\
\text { below } 5 \text { th percentile } \\
\text { and } 0.6 \% \text { were above } \\
\text { the } 95 \text { th percentile for } \\
\text { weight, mean BMl } 18.0\end{array}$ & $\begin{array}{l}\text { A medical checkup } \\
\text { with emphasis on } \\
\text { assessment of } \\
\text { reproductive health } \\
\text { and nutritional status } \\
\text { detected almost same } \\
\text { number of } \\
\text { reproductive health } \\
\text { problems as reported } \\
\text { by participants in } \\
\text { survey (no statistical } \\
\text { analysis done) } \\
\text { Disparities identified } \\
\text { between those } \\
\text { students who report } \\
\text { health problems ( } 72 \% \\
\text { of girls, } 56 \% \text { of boys), } \\
\text { and those who } \\
\text { voluntarily sought help } \\
\text { at clinic at baseline } \\
\text { ( } 43 \% \text { girls, } 35 \% \text { boys) }\end{array}$ \\
\hline 3 & & & $\begin{array}{l}\text { Reported percent } \\
\text { change in health } \\
\text { service utilization } \\
\text { among young } \\
\text { married women from } \\
\text { baseline to endline: } \\
\text { (*=significant) } \\
\text { Higher use of spacing } \\
\text { FP methods: social } \\
\text { mobilization group } \\
\text { (SM) 14.4*, government } \\
\text { services group (GS) } \\
14.1^{*}, \text { SM+GS } 12.4\end{array}$ & 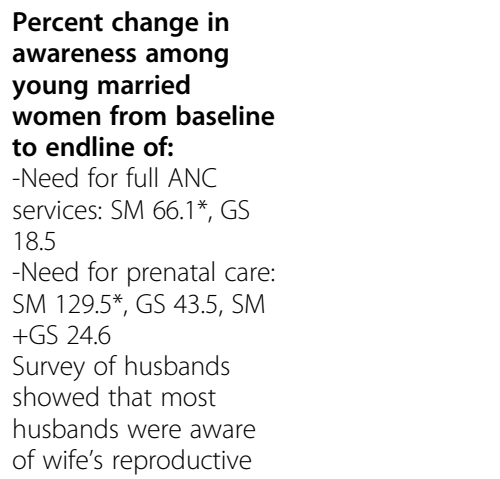 & $\begin{array}{l}\text { Social mobilization } \\
\text { relatively effective in } \\
\text { improving young } \\
\text { married women's RH } \\
\text { knowledge (on its own } \\
\text { or with other } \\
\text { government services) } \\
\text { Strengthening of } \\
\text { government services } \\
\text { alone did not perform } \\
\text { significantly better } \\
\text { than other sites on } \\
\text { most outcomes } \\
\text { Also showed } \\
\text { improvement in }\end{array}$ \\
\hline
\end{tabular}


Table 6 Main findings of research studies $(\mathrm{N}=12)$ (Continued)

More attendance to ups: SM 40.5*, GS -17.8 -Higher use of high-risk delivery care: SM 4.7

GS 4.2, SM+GS 29.8*

More having received

treatment for

reproductive or sexual infection symptoms:

SM 79.5, GS 44.8, SM +GS $98.2^{*}$ prenatal care check-

health needs (in terms

of maternal health), yet

even knowledgeable

husbands unlikely to

be involved in

maternal care due to

social norms that

discourage their

participation (no

significance testing

performed)

Interviews showed that

mothers-in-law were

more likely to be sup-

portive by end of pro-

ject than at baseline

(no quantitative com-

parison performed)

Significantly more adolescents used school-based clinic services than dispensarybased $33 \%$ versus

$13.5 \%, p<0.01)$

The majority of

students using schoolbased clinics were 13-

$15 y(60 \%)$ versus the

majority of students

using dispensary-based

clinics were 16-19

(40\%), $p<0.001$.
Majority of participants

(80.8\%) reported

having a health

problem during 3-

months prior to survey.

Of those, 38\% were

"psychological" prob-

ems (tension about

career, studies, weight/

height

$64 \%$ of girls and $42.3 \%$

of boys sought help/

care for health

problems, but very few

consulted a doctor

(most approached

friends or parents)

Most common

problems presenting to

clinic were

psychological (29\%),

general health

problems (25\%), and

behavioural (16\%)

Significantly higher

proportion of

adolescents with

psychological and

behavioural problems

reported in school-

based clinic whereas

higher proportion of

medical problems were

presented in dispens-

ary based clinic

$(p<0.05)$

Demand for

contraceptive use

increased from 25\%

baseline to $40 \%$ at

follow-up in interven-

tion community (un-

changed in

comparison)

Contraceptive use

odds ratio 3.8

comparison vs.

comparison

communities husbands' and

mothers-in-laws' atti-

tudes regarding young

married women repro-

ductive health needs in

terms of maternal

health 
Table 6 Main findings of research studies ( $N=12)$ (Continued)

Knowledge that fertility varies during menstrual cycle and agreement that early child birth can be harmful, contraceptive use is necessary and safe for delaying first births higher in interventional than comparison communities (odds ratio 1.6-3.0)

Satisfaction level of clients in ARSH clinics varied by site: Significantly higher proportion of ARSH clients at Chandigarh reported being very satisfied with service vs. those at other clinics ( $90 \%$ vs. $66 \%$, $\mathrm{p}=0.004$ )

No significant differences between ARSH and other clinics in Delhi or Kolkata.

Accessibility of ARSH clinics varied by site: Significantly higher proportion of ARSH clients at Chandigarh described easy accessibility of service vs. those at other clinics (70\% vs. $54.3 \%$, $\mathrm{p}$ value not reported) No significant differences between ARSH and other clinics in Delhi or Kolkata. ARSH clients in Chandigarh and Kolkata more frequently described comfortable waiting area (Chandigarh 50\% vs. $34.4 \%, p=0.04$ Kolkata $32 \%$ vs. 10.2 $\mathrm{p}=0.003)$,

Health care providers were generally better reviewed by users in AFHCs than other clinics, no significance levels reported.

Strategy of drawing adolescents to AFHCs at health

1565 adolescents used services during 3 years research compared to 3250 over subsequent posts amidst other 3 year scale up phase clients for reproductive Attendance of boys at centers was lower than health services was girls (specific numbers feasible not indicated)

Community Proportions of health sensitisation with
Increased knowledge of boys and girls on $\mathrm{SRH}$ issues (proportions or significance testing not specified) Increased contraceptive acceptance to $86 \%$ Increased awareness of ARHCs and range of services among boys
No baseline given, increased awareness of services). No comparison group. 
Table 6 Main findings of research studies $(\mathrm{N}=12)$ (Continued)

\begin{tabular}{|c|c|}
\hline $\begin{array}{l}\text { involvement of } \\
\text { gatekeepers was } \\
\text { feasible and } \\
\text { important } \\
\text { Peer volunteer } \\
\text { approach not } \\
\text { successful, but } \\
\text { rather clients were } \\
\text { referred to center } \\
\text { by health care } \\
\text { providers } \\
\text { IEC activities } \\
\text { through local } \\
\text { television network } \\
\text { and pamphlets } \\
\text { were not effective }\end{array}$ & $\begin{array}{l}\text { boys and girls sought } \\
\text { services were } \\
\text { compared between } \\
\text { research and scale-up } \\
\text { phases (No significance } \\
\text { testing specified): } \\
\text { Boys: Seeking } \\
\text { contraceptives: 17.4\% } \\
\text { during research vs. } \\
4.3 \% \text { during scale-up, } \\
\text { information and coun- } \\
\text { selling on growing up/ } \\
\text { sexual concerns } 62 \% \text { vs } \\
67.5 \% \\
\text { Girls: seeking } \\
\text { contraceptives } 21.8 \% \\
\text { vs. } 11.6, \text { information/ } \\
\text { counselling on } \\
\text { growing up/sexual } \\
\text { concerns } 15.4 \% \text { vs. } \\
79.3 \% \text {, menstrual } \\
\text { concerns } 20.8 \text { vs. } 9.5 \%\end{array}$ \\
\hline
\end{tabular}

and girls from $0 \%$ to 77\% (no significance testing specified)

(1)


Table 6 Main findings of research studies ( $\mathrm{N}=12)$ (Continued)

10

11 1st birth and space

2nd birth than non-

participants

Main qualitative

findings:

Situation in Bihar is

improving in terms of

education, delayed

marriage, small families;

patriarchal norms still

deeply rooted,

PRACHAR played role

in changing

community

perceptions on girls'

education, age, at

marriage, SRH

Significant

Baseline data of

adolescent girls:

improvements

observed between pre-

test and mid-point and

pre-test and follow-up

scores; not between

mid-point and follow-

up scores

Satisfactory

improvement in all 8

AWWs re: use of

Mean KAP score was

28.56 out of 48 total-

knowledge related the

contraception, mastur-

bation, reason of ado-

lescent changes, and

reason of initial irregu-

lar menstruation after

menarche was

anemia self-assessment unsatisfactory

chart for screening of Health seeking

anemia, E-chart for vi-

sion, weighting scale

and measure tape for

$\mathrm{BMI}$ and record book

keeping

Communication skills

(better history taking

re: menstruation, diet

and effective health

education also

improved in all 8

AWWs)

Before study, no

enrolment of

adolescent girls in

Anganwadis before

study, no health check-

up carried out by

AWWs, no girls being

given IFA tablets, no

IEC activities related to

AFHS found at Angan-

wadi centers behaviour was poor

(21\% unaware that

they are beneficiaries

of Anganwadi and 11\%

unaware about

facilities for their

healthcare

Majority (82\%) of

adolescent girls were

undernourished
Odds of contraceptive use were $5 x$ higher in intervention group

than comparison

group for females; for males 3.6x higher.
Median age was 2.6 years higher in intervention females, 2.8 years higher in intervention males than comparison group.

Relative Risk of marriage by time of survey (after adjusting for schooling and caste differences) was $44 \%$ lower for females and 26\% lower for 
Table 6 Main findings of research studies ( $N=12)$ (Continued)

12

AFC Adolescent Friendly Centre

AFHC: Adolescent Friendly Health Centre

AFHS/YFHS Adolescent/Youth Friendly Health Service

ARSH Adolescent Sexual and Reproductive Health

ASHA Accredited Social Health Activist

ANM Auxiliary Nurse Midwife

AWW Aangan Wadi Worker

$B M I$ Body Mass Index

CHC Community Health Center

IFA Iron Folic Acid

$M O$ Medical Officers

NGO Non Government Organization

$K A P$ Knowledge, Attitudes and Practices

PHC: Primary Health Centre

$R H$ Reproductive Health

RSH Reproductive and Sexual Health

SC Sub Centre

SDH Sub-District Hospital

$S R H$ Sexual and Reproductive Health

SRHS Sexual and Reproductive Health Services males in intervention

than comparison

Age at first birth also

lower in intervention

than control group

(after adjusting for

marriage, education,

caste)
Majority of clients wer

they received from

facility (Arajiline 82\%

vs. Hosakote 65\%),

relative change of

utilization of services

was significantly higher

in Arajiline than

Hosakote
More adolescents were

aware of services in

Hosakote (56-75\%) vs.

Arajiline (67\% to 97\%)

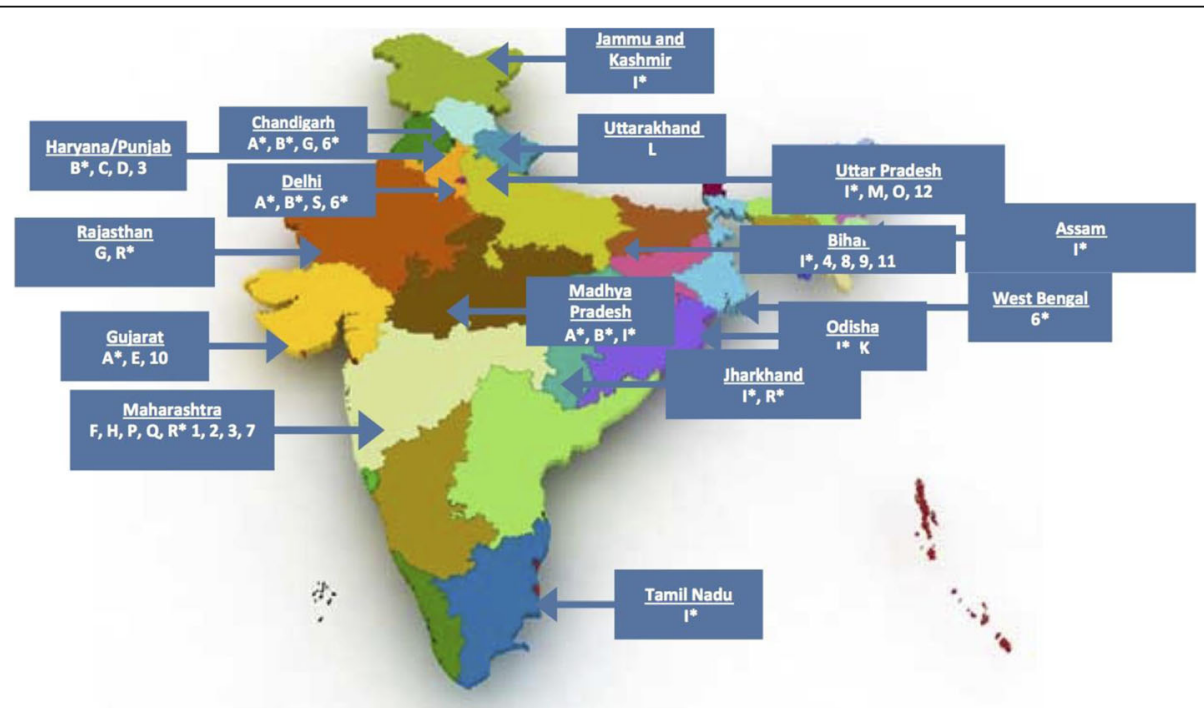

Fig. 2 Geographic distribution of evaluations (labelled A through S) and studies (labelled 1 through 12) of adolescent friendly health service initiatives in India 
situation analysis, and those using combinations of designs. A descriptive design was used in most evaluations/studies $(E, F, G, H, I, K, M, O, P, R, S ; \quad 2,4,12)$, quasiexperimental in $10(A, B, C, D, J, L ; 5,6,8,11)$, a feasibility assessment in one $(Q)$ and combinations of designs in five $(1,3,7,9,10)$.

The most commonly utilized methodology was a simple post-implementation, cross-sectional analysis without a comparison group, found in 18 evaluations/studies ( $E, F, G, H, I, K, M, O, P, R ; 1,2,3,4,9,10,11)$. In contrast, eight $(B, J, L ; 1,3,5,7,10)$ applied a pre- and post-implementation (i.e. baseline and follow-up) analysis without comparison groups. We also observed the comparison of "exposed" (facilities/participants who received an AFHS intervention) versus those who were "non-exposed" (facilities/participants who had not received an AFHS intervention): this was used in five evaluations/studies $(A, D ; 3,6,11)$.

In addition to quantitative analytic methods, many evaluations/studies utilized qualitative methods by means of key informant interviews, in-depth client interviews, or focus group discussions to assess various aspects of an AFHS initiative. Qualitative methods were used in 15 evaluations/studies (E,F,G,M,O,P,R,S; $1,2,3,6,7,9,12)$. Details specific to the qualitative analytic techniques were rarely described.

Facility checklists were utilized in a number of evaluations/studies $(C, E, F, G, I, K, L, M, P, S)$, and facility attendance records were analysed in five $(2,4,6,7,12)$. Provider interviews or questionnaires were used in nine $(E, F, G, K, P, R, S$; $6,10)$ while adolescent client interviews or questionnaires were used in 12 reports $(A, B, C, F, G, M, O, P, R, S ; 6,12)$. One (R) employed mystery clients. Standard definitions of quality varied widely and were inconsistently described in the reports. Only four reports (C,F,Q,P) specifically reported on the seven standards of quality noted in (Table 1) using the quality criteria set out in the Ministry's implementation guide. (Reference 1), while others (H,K,P,S) describes quality measures that were similar to these standards but not explicitly standardized.

\section{What was the nature and extent of facilities and service users included in the evaluations/studies?}

Where descriptions were provided, there was variability in the nature and extent of health facilities and adolescent users included. Many reports did not contain this information. When information was available, as we found in thirteen evaluations/studies (C,D,E,F,G,I $K, L, M, P Q, R, S)$, the size and distribution of target adolescent populations receiving an AFHS intervention was rarely stated. An exception was D, which reports that each cluster of three villages has an estimated adolescent population of 3000-5000, of those approximately 600 adolescents were sampled in each village. Thus, it was often challenging to assess representative nature of a sample or generalizability of the report.

Many reports noted number and kind of health facilities included in the context of a facility assessment (for example, one evaluation in Gujarat $(E)$ included twentyone facilities, representing $50 \%$ of all ARSH facilities in the intervention community and one in Rajasthan $(G)$ covered 12/110 operating adolescent friendly health clinics (11\%), including one of each facility type (district hospital, community health centre, and primary health centre) from each of the four selected districts. From these, evaluators sampled adolescent clients and service providers and also observed facilities using a checklist. Some reports described the number of health service providers or stakeholder interviews, for example, report $E$ describes that three state officials, nine district officials, seventeen medical officers, and nineteen grassroots level health workers were interviewed.

We could not infer the representativeness of users surveyed from the information provided. While all evaluations/studies that included surveys or interviews with adolescent clients indicated number of adolescents interviewed, typically stratified by age, rarely did reports describe the sampling population from which these survey participants were drawn or how representative of the sample population they were. Where qualitative methodology was adopted, multiple reports described the number of focus group discussions conducted without indicating the number of participants included in each focus group $(E, M ; 9)$.

\section{What were the main findings of the evaluations/studies? Process}

Very few reports commented on process outcomes, specifically programme design or fidelity of programme implementation, and whether any mid-course adaptations were made. The exceptions were report $Q$, which included specific comments about process of programme design, and a few which examined feasibility of programmes $(B, Q ; 1)$ or commented on challenges of implementation or monitoring $(E, C, F, G, L)$. Quality was assessed variably across evaluations/studies, with the minority that used the adapted Ministry standards demonstrating an increase across all quality standards compared to control groups or previous time intervals. Persistent unmet quality standards were noted: lack of ensuring adequate equipment and supplies $(P)$, inadequate awareness in the community about services $(C, F, Q)$ and inadequate management systems in place $(C, F)$.

\section{Outputs}

More evaluations/studies described outputs, with 11 evaluations $(D, E, G, H, M, 1,2,3,4,7,12)$ including assessments of 
service utilization. All but one report $(G)$ reported that utilization increased as a result of an AFHS initiative. However, not all results were presented with baseline data.

\section{Health knowledge and behaviour outcomes}

In general, programmes designed to make health services more adolescent friendly resulted in increased knowledge about RSH needs of adolescents, both among service users themselves $(A, B, D, L, R, S ; 1,3,5,7,10,12)$ and among health service providers $(K, 10)$. Furthermore, a number of evaluations/studies commented on acceptance of the programme by gatekeepers in the community, such as parents $(B, C ; 1,3)$. The most common behaviour outcomes evaluated were self-reported sexual health behaviours, such as condom or contraceptive use $(A, J, L ; 5,9,11)$. In these studies/evaluations, AFHS exposure was associated with increased reported contraceptive and sanitary pad use.

\section{Programme results/impact}

A small number of initiatives evaluated programme results/impacts such as levels of delayed first birth $[9,11]$ or anaemia $(B, 2)$, and an early study (A) of CEDPA Better Life Options Programme examined mean number of children and rates of child deaths-finding both to be decreased. The PRACHAR intervention (11) demonstrated greater age at marriage and first birth at the community level.

Using the SQUIRE-adapted scoring system consisting of fifteen questions, the mean quality score averaged between two independent scorers was 8.1/15 (54\%). Interrater reliability for scores in independent domains was variable (kappa $=0.122, p=0.014$ ), however the average mean quality score was not significantly different $(8.53$ vs. $7.63, p=0.291$ ).

\section{Discussion}

This is the first study to systematically review a body of country-specific evaluations and studies of AFHS initiatives and to draw conclusions about their quality and their effects. We found that at least 30 independent evaluations and studies have been conducted over a wide geographic distribution of India since 2000. They have been carried out primarily by NGOs and academic institutions and have focused on government-sponsored AFHS programmes or independent NGO initiatives to strengthen government services. They focused primarily on service utilization trends and health behavioural outcomes and less frequently on design and implementation of AFHS. The rationale for sampling strategies was not uniformly described in evaluation reports making it challenging to assess the generalizability of the findings. Further, study designs most commonly used were descriptive or quasi-experimental in nature, and frequently lacked a comparison group to draw inferences on effectiveness of initiatives. Future evaluations and studies should be better designed and implemented and should pay more attention to process and long term impact.

Most evaluations/studies demonstrated improvement in the quality of services as a result of government or NGO initiatives to make services more adolescentfriendly. Many also showed an improvement in adolescent knowledge levels of RSH issues, and in health behaviours, such as use of contraception, while few demonstrated positive programme results/impacts.

While much national and international attention has been paid to improving the quality of health systems for adolescents, few efforts to do so have been rigorously studied [14]. It is evident from these evaluation and study reports that a standard approach to evaluation of AFHS has not been adopted. The WHO has developed and promoted the application of its Quality Assessment Guidebook [15] which could facilitate greater comparability across evaluations/studies, but using it will require support -one evaluation $(F)$ specifically referenced using WHO quality assessment tools, describing them as "very elaborate and time consuming" and needing to be simplified for local use.

The publication dates reveal that the volume of evaluations and studies of AFHS has increased over time, which is likely attributable to the establishment of the National Health Mission policy and accompanying resources made available for AFHS both by the Government of India and others. Some geographic regions like Maharashtra and Bihar are more represented than others, which may reflect differences in state government support of evaluation resources or external agency interest.

Reviews and syntheses of AFHS in low- and middleincome countries (LMICs) have been conducted at the global level. An example of the former is a review of research and evaluation evidence in improving the quality and use of SRH services by adolescents in LMICs. It found the most robust evidence for programmes using a combination of approaches including health worker training and facility improvements as well as strategies for demand generation and community acceptance [15]. An example of the latter is synthesis of programmatic outputs (i.e. quality and coverage) and service utilization in eight LMIC countries, which concluded that with support, government-run health facilities can improve the quality of health services and their utilization by adolescents [16].

Moving to measures and methods, a systematic review of indicators of youth-friendly health care in high-, middle-, and low-income countries, identified 22 studies, 15 
of which used quantitative methods, six used qualitative methods, and one used mixed methodology [17]. The review further expanded upon eight domains as central to young people's positive experience of care, including accessibility of health care, staff attitude, communication, medical competency, guideline-driven care, age appropriate environments, youth involvement in health care, and health outcomes. Certain attributes, particularly staff attitudes that were respectful and friendly, were universally applicable while some domains such as clean environment were more dependent to context. While understanding the most appropriate quality indicators is paramount to valuable evaluation, there is little research examining strengths and weakness of different evaluation designs. A recently published post hoc evaluation of a multi-country study on adolescent health provides pointers on good practice in designing and executing studies and evaluations [16]. More attention is needed on the strengths and weakness of different study and evaluation designs on AFHS.

\section{Limitations}

The variety of ways in which evaluations and studies are published and disseminated, ranging from peer-reviewed journals to NGO reports may have limited our ability to access all existing reports. We included only publicly available reports and peer-reviewed journal articles, which may have further limited our access to evaluation reports that have not yet been placed in public domain or may be currently in progress. Further, a publication bias for positive results may have influenced the findings of our review, although our search included reports published outside of the peer-review process. Because the evaluations ranged from brief reports to full evaluation summaries, it is possible that only select findings have been made publicly availably but more thorough evaluation data exists. Furthermore, only few publications provided copies of uniquely developed assessment tools for application in other settings. This presents challenges in comparing evaluation findings across states and also suggests the potential benefit of disseminating validated tools for shared use.

\section{Conclusions}

Evaluations and studies of AFHS initiatives in India are being performed and disseminated. The strengths of these evaluations include clearly stated objectives, frequent use of multiple data sources, and assessment of programmatic outputs as well as health outcomes and impacts. We observed significant variability across study designs in these evaluations, and the target populations and comparison groups were inconsistently defined. Our findings demonstrate that AFHS initiatives have demonstrated improvements in healthcare quality and utilization by adolescents, increased SRH knowledge, and in some settings, improved sexual health behaviours such as condom and contraception use.

India's new Adolescent Health Programme - Rashtriya Kishor Swasthya Karyakram aims to broaden strategies for community-based health promotion and to strengthen preventive, diagnostic, and curative services for adolescents across levels of health facilities [17]. This programme highlights the importance of strong monitoring and evaluation systems, thus it is vital to build upon current knowledge of best evaluation practices in order to ensure the greatest impact to adolescent populations in India and worldwide.

\section{Appendix 1}

\section{Medline search strategy}

We chose to begin our search in 2000 because the International Conference on Population and Development +5 review (1999) reiterated the importance of enabling adolescents to obtain the health services they need and renewed attention and support for action in this area [18].

Searched 21/7/14: PubMed 152 Results

(("adolescent health services"[major] OR "adolescent health services"[tw] OR (("adolescent-friendly"[tiab] OR "adolescent friendly"[tiab] OR "youth friendly"[tiab] OR "youth-friendly"[tiab]) AND ("healthcare services"[tiab] OR "health care"[tiab] OR "health services"[tiab] OR health services[mesh] OR preventive health services[mesh] OR "preventive health services"[tw])) OR school health services[mesh] OR "school health services"[tw]) OR ("reproductive health services"[major] OR "reproductive health services"[tiab] OR "sexual health services"[tiab] $O R$ "reproductive and sexual health services"[tiab] OR "sexual and reproductive health services"[tiab] OR "sexual reproductive health services"[tiab] OR "reproductive sexual health services"[tiab])) AND ("India"[mesh] OR "India"[tiab] OR "India"[ot]) AND ("young adult"[mesh] OR "adolescent"[mesh] OR "minors"[mesh] OR adolescen*[tiab] OR teen*[tiab] OR juvenile[tiab] OR preteen*[tiab] OR pre-teen*[tiab] OR youth[tiab]) AND ("2000/ 01/01"[PDAT] : "3000/12/31"[PDAT]) AND ("adolescent"[MeSH Terms] OR "young adult"[MeSH Terms]) AND English[lang]

\section{Appendix 2 \\ EMBASE search strategy}

21/7/14: EMBASE 9 results

'adolescent friendly' OR 'youth friendly' AND ('health service'/exp OR 'health service' OR 'reproductive health'/ $\exp O R$ 'reproductive health' OR 'evaluation'/exp OR 'evaluation') AND ('india'/exp OR 'india') AND [20002014]/py AND [embase]/lim NOT [medline]/lim 


\section{Appendix 3}

\section{PRISMA Diagram}

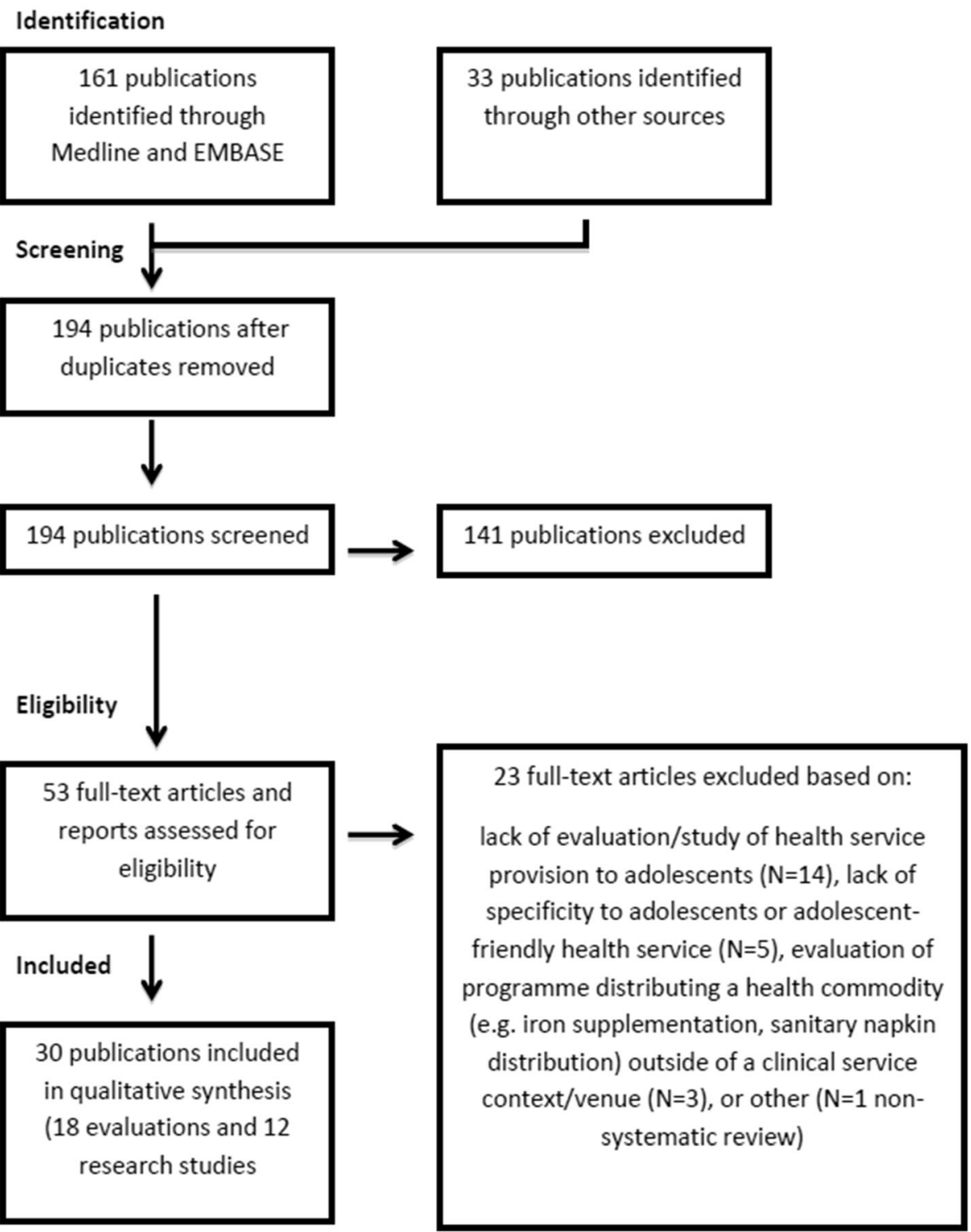




\section{Appendix 4}

\section{Peer-reviewed publications that were reviewed in full-text and excluded}

Table 7 Peer-reviewed publications that were reviewed in full-text and excluded

\begin{tabular}{|c|c|c|}
\hline Author, date & Description & Reason for exclusion \\
\hline Andrew et al, 2003 [19] & Mixed methods study of needs and preferences of adolescents & No evaluation of health services \\
\hline Biswas et al, 2002 [20] & $\begin{array}{l}\text { Pre- and post- evaluation of RCH workshops for providers and program } \\
\text { managers }\end{array}$ & Not specific to ARSH or AFHS \\
\hline Calhoun et al, 2013 [21] & $\begin{array}{l}\text { Mixed methods study of provider imposed restrictions to clients' access to } \\
\text { family planning in urban Uttar Pradesh. }\end{array}$ & $\begin{array}{l}\text { No mention of adolescent-specific } \\
\text { services }\end{array}$ \\
\hline Char et al, 2011 [22] & $\begin{array}{l}\text { Descriptive study of young men's knowledge and attitudes regarding family } \\
\text { planning methods and sources of info. }\end{array}$ & No evaluation of health services \\
\hline Char et al, 2010 [23] & $\begin{array}{l}\text { Qualitative study of influence of mothers-in-law on young couples' family } \\
\text { planning decisions. }\end{array}$ & No evaluation of health services \\
\hline $\begin{array}{l}\text { Collumbien et al, } 2011 \\
\text { [24] }\end{array}$ & $\begin{array}{l}\text { Descriptive study service utilization among young people prior to two large } \\
\text { interventions }\end{array}$ & No evaluation of health services \\
\hline Das et al, 2006 [25] & $\begin{array}{l}\text { Descriptive study of disease burden and treatment seeking behaviour among } \\
\text { adolescent girls }\end{array}$ & No evaluation of health services \\
\hline de Souza, 2014 [26] & Descriptive study of roles performed by peer HIV workers & Program not specific to adolescents \\
\hline Dongre et al, 2011 [27] & $\begin{array}{l}\text { Evaluation of a school-based health program involving formation of school } \\
\text { health committee and committee activities including deworming and IFA } \\
\text { supplementation }\end{array}$ & $\begin{array}{l}\text { Health commodity distribution } \\
\text { without clinical health services }\end{array}$ \\
\hline Hazarika et al, 2009 [28] & $\begin{array}{l}\text { Descriptive study of adolescent utilization of contraceptive and ANC services } \\
\text { as well as in-facility delivery }\end{array}$ & No evaluation of health services \\
\hline Kotecha et al, 2009 [29] & $\begin{array}{l}\text { Evaluation of a school-based health program involving IFA supplementation } \\
\text { and health education }\end{array}$ & $\begin{array}{l}\text { Health commodity distribution } \\
\text { without clinical health services }\end{array}$ \\
\hline Mishra et al, 2012 [30] & Descriptive study of treatment-seeking behaviour of adolescent girls & No evaluation of health services \\
\hline Nair et al, 2012 [31] & $\begin{array}{l}\text { Descriptive study of adolescent knowledge, attitude and practice related to } \\
\text { reproductive and sexual health }\end{array}$ & No evaluation of health services \\
\hline Nair et al, 2012 [32] & $\begin{array}{l}\text { Comparative study of adolescent boys vs. girls' knowledge, attitude and } \\
\text { practice related to reproductive and sexual health }\end{array}$ & No evaluation of health services \\
\hline Nair et al, 2012 [33] & $\begin{array}{l}\text { Comparative study of married male vs. female young adults knowledge, } \\
\text { attitude and practice related to reproductive and sexual health }\end{array}$ & No evaluation of health services \\
\hline Nair et al, 2012 [34] & Descriptive study of perceptions of community stakeholders & No evaluation of health services \\
\hline Nath et al, 2008 [35] & Non-systematic review of AFHS & $\begin{array}{l}\text { Does not include specific evaluations } \\
\text { and their methodologies }\end{array}$ \\
\hline Rao et al, 2008 [36] & $\begin{array}{l}\text { Evaluation of a school-based reproductive health education program } \\
\text { among adolescent girls }\end{array}$ & No evaluation of health services \\
\hline Sabarwal et al, 2012 [37] & $\begin{array}{l}\text { Descriptive study of treatment seeking behaviour for reproductive tract } \\
\text { infections among young women }\end{array}$ & No evaluation of health services \\
\hline Shah et al, 2013 [38] & Evaluation of sanitary pad distribution program & $\begin{array}{l}\text { Health commodity distribution } \\
\text { without clinical health services }\end{array}$ \\
\hline Sharma et al, 2012 [39] & Evaluation of male reproductive health program & Program not specific to adolescents \\
\hline Singh et al, 2012 [40] & $\begin{array}{l}\text { Descriptive study of health care utilization among married adolescent } \\
\text { women }\end{array}$ & $\begin{array}{l}\text { No evaluation of health services, } \\
\text { not specific to AFHS }\end{array}$ \\
\hline Speizer et al, 2012 [41] & $\begin{array}{l}\text { Descriptive study of family planning service utilization trends in } \\
\text { Uttar Pradesh }\end{array}$ & $\begin{array}{l}\text { No specific data for adolescent } \\
\text { or evaluation of AFHS }\end{array}$ \\
\hline
\end{tabular}




\section{Abbreviations}

AFHS: Adolescent friendly health services; CEDPA: The center for development and population activities; CORT: Centre for operational research and training; MeSH: Medical subject heading; NGO: Non-governmental organizations; RSH: Reproductive and sexual health; WHO: World health organization

\section{Acknowledgements}

None

\section{Funding}

Authors received no financial support from any organization for the submitted work. Dr. Hoopes' training was supported by a National Research Service Award T32 MH 20021-16 for Psychiatry and Primary Care as well as a Leadership Education in Adolescent Health (LEAH) training grant. Her internship period at WHO was supported by grants from University of Washington's Center for AIDS Research (CFAR) and Global Center for the Integrated Care of Women, Adolescents, and Children (Global WACh) as well as the American Academy of Pediatrics International Elective Award and Corkery Family Fellowship Travel Award.

\section{Availability of data and materia}

Please contact corresponding author for data requests beyond what is available in tables and appendix.

\section{Authors' contributions}

$\mathrm{AH}$ conducted data collection, carried out analysis, drafted the initial manuscript, and approved the final manuscript as submitted. PA conducted data collection, carried out the analysis, reviewed and revised the manuscript, and approved the final manuscript as submitted. SB provided input on study methodology, reviewed and revised the manuscript, and approved the final manuscript as submitted. VCM conceptualized and designed the study, supervised the analysis, reviewed and revised the manuscript, and approved the final manuscript as submitted.

\section{Authors' information}

No additional information.

\section{Competing interests}

All authors declare that they have: received no support from any organisation for the submitted work; no financial relationships with any organisations that might have an interest in the submitted work in the previous 3 years; no other relationships or activities that could appear to have influenced the submitted work.

\section{Consent for publication}

All authors have approved this final version of the manuscript.

\section{Ethics approval and consent to participate}

Not applicable as manuscript does not report on or involve use of any individual animal or human data or tissue.

\section{Author details}

${ }^{1}$ Department of Pediatrics, University of Colorado School of Medicine, 13123 East 16th Avenue, Box B025, Aurora, CO, USA. ${ }^{2}$ Department of Community Medicine, Maulana Azad Medical College, New Delhi, India. ${ }^{3}$ Department of Community and Behavioral Health, Colorado School of Public Health, 13001 E. 17th Place, B119, Bldg 500, Room, E3345A Aurora, USA. ${ }^{4}$ Anschutz Medical Campus, Aurora, CO 80045, USA. ${ }^{5}$ Division of Reproductive Health and Research, World Health Organization, Avenue Appia 20, 1211 Geneva 27, Switzerland.

Received: 24 June 2016 Accepted: 28 October 2016 Published online: 15 November 2016

\section{References}

1. National Rural Health Mission. Implementation guide on RCH II adolescent reproductive sexual health strategy for state and district programme managers [Internet]. 2006. Available from: http://www.searo.who.int/entity/ child_adolescent/topics/adolescent_health/rch_asrh_india.pdf
2. Government of India. National Health Mission, Ministry of Health \& Family Welfare [Internet]. Available from: http://nrhm.gov.in

3. Jejeebhoy S, Santhya K. Sexual and reproductive health of young people in India: A review of policies, laws and programmes. New Delhi. 2011.

4. Uttekar B, Kanchan L, Sandhya B. Sexual and Reproductive Health and Unmet Needs of Family Planning Among Young People in India: A Review Paper. Vadodara. 2012.

5. Government of India/Ministry of Health and Family Welfare. National Health Mission Components, RMNCH + A, Adolescent Health:Background [Internet]. Available from: http://nrhm.gov.in/nrhm-components/rmnch-a/adolescenthealth/adolescent-health/background.html

6. World Health Organization. Adolescent Friendly Health Services - An Agenda for Change. 2002.

7. Patton M. Utilization-focused evaluation: The new century text, 1997. Sage, Thousand Oaks, CA [Internet]. 1997:0:431. Available from: http://scholar. google.com/scholar?hl=en\&btnG=Search\&q=intitle:Utilization-Focused +Evaluation:+The+New+Century+Text\#0

8. Lohr KN, Steinwachs DM. Health Services Research: An Evolving Definition of the Field. Heal Serv Res. 2002;37(1):15-7.

9. Moher D, Liberati A, Tetzlaff JAD. PRISMA 2009 Flow Diagram. The PRISMA statement. 2009. p. p. 1000097

10. Moher D, Shamseer L, Clarke M, Ghersi D, Liberati A, Petticrew M, et al. Preferred Reporting Items for Systematic Review and Meta-Analysis Protocols (PRISMA-P) 2015 statement. Syst Rev [Internet]. 2015;4(1):1. Available from: http://www.pubmedcentral.nih.gov/articlerender.fcgi?artid= 4320440\&tool=pmcentrez\&rendertype=abstract

11. Ogrinc G, Davies L, Goodman D, Batalden P, Davidoff F, Stevens D. Squire 2.0 (standards for quality improvement reporting excellence): Revised publication guidelines from a detailed consensus process. Am J Crit Care. 2015;24(6):466-73.

12. Ogrinc G, Mooney SE, Estrada C, Foster T, Goldmann D, Hall LW, et al. The SQUIRE (Standards for QUality Improvement Reporting Excellence) guidelines for quality improvement reporting: explanation and elaboration. Qual Saf Health Care. 2008;17(1):113-32.

13. Davidoff F, Batalden P, Stevens D, Ogrinc G, Mooney S. Publication guidelines for quality improvement studies in health care: Evolution of the SQUIRE project. J Gen Intern Med. 2008:23:2125-30.

14. Denno DM, Hoopes AJ, Chandra-Mouli V. Effective Strategies to Provide Adolescent Sexual and Reproductive Health Services and to Increase Demand and Community Support. J Adolesc Heal.

15. World Health Organization. Quality assessment guidebook: A guide to assessing health services for adolescent clients. 2009.

16. Ivanova O, Pozo KC, Segura ZE, Vega B, Chandra-Mouli V, Hindin MJ, et al. Lessons learnt from the CERCA Project, a multicomponent intervention to promote adolescent sexual and reproductive health in three Latin America countries: a qualitative post-hoc evaluation. Eval Program Plann [Internet]. Elsevier Ltd; 2016;58:98-105. Available from: http://dx.doi.org/10.1016/j. evalprogplan.2016.06.007

17. Rashtriya Kishor Swasthya Kayrakram. Strategy Handbook. New Delhi. 2014.

18. Nanda A, Mehrotra F, Verma R, Nanda P, \& Masilamani R. Evaluation Report of UNFPA India Country Programme-7 UNFPA Country Office, India Evaluation Team. 2011

19. Andrew G, Patel V, \& Ramakrishna J. Sex, studies or strife? What to integrate in adolescent health services. Reproductive Health Matters. 2003. (http://doi. org/10.1016/S0968-8080(03)02167-0)

20. Biswas R. An overview of multicentric training workshops for public health professionals on reproductive and child health programme in India. Indian J Public Health. 2002:46(3):78-85.

21. Calhoun LM, Speizer IS, Rimal R, Sripad P, Chatterjee N, Achyut P, Nanda P. Provider imposed restrictions to clients' access to family planning in urban Uttar Pradesh, India: a mixed methods study. BMC Health Serv Res. 2013;13: 532 (http://doi.org/10.1186/1472-6963-13-532)

22. Char A, Saavala M, Kulmala T. Assessing young unmarried men's access to reproductive health information and services in rural India. BMC Public Health. 2011:11(1):476. http://doi.org/10.1186/1471-2458-11-476.

23. Char A, Saavala M, Kulmala T. Influence of mothers-in-law on young couples' family planning decisions in rural India. Reprod Health Matters. 2010;18(35):154-62. http://doi.org/10.1016/S0968-8080(10)35497-8.

24. Collumbien M, Mishra M, Blackmore C. Youth-friendly services in two rural districts of West Bengal and Jharkhand, India: Definite progress, a long way to go. Reprod Health Matters. 2011;19:174-83. http://doi.org/10.1016/S09688080(11)37557-X. 
25. Das D. Morbidity and treatment seeking behavior among adolescent girls in a rural area of North 24 Parganas district, West Bengal. Indian J Public Health. 2006;50(4):242-3.

26. De Souza R. A Qualitative Study of Roles Performed by Peer Workers in the Context of HIV in India. J Assoc Nurs AIDS Care. 2014;25:176-87. http://doi. org/10.1016/j.jana.2013.01.004.

27. Dongre AR, Deshmukh PR, Garg BS. Health-promoting school initiative in Ashram schools of Wardha district. Natl Med J India. 2011;24(3):140-3. Retrieved from http://www.ncbi.nlm.nih.gov/pubmed/21786841.

28. Hazarika I. Women's reproductive health in slum populations in India: evidence from NFHS-3. J Urban Health. 2010;87(2):264-77. http://doi.org/10. 1007/s11524-009-9421-0.

29. Kotecha PV, Patel SV, Mazumdar VS, Baxi RK, Misra S, Diwanji M, Shringarpure K. Reproductive health awareness among urban school going adolescents in Vadodara city. Indian J Psychiatry. 2012;54(4):344-8. http:// doi.org/10.4103/0019-5545.104821.

30. Mishra SK, Mukhopadhyay S. Socioeconomic correlates of reproductive morbidity among adolescent girls in Sikkim, India. Asia-Pac J Public Health. 2012;24(1):136-50. http://doi.org/10.1177/1010539510375842.

31. Nair MKC, Leena ML, Thankachi Y, George B, Russell PSS. ARSH 1: Reproductive and Sexual Health Problems of Adolescents and Young Adults: A Cross Sectional Community Survey on Knowledge, Attitude and Practice. Indian J Pediatr. 2013;80 Suppl 2:192. http://doi.org/10.1007/ s12098-013-1136-2.

32. Nair MKC, Leena ML, George B, Thankachi Y, Russell PSS. ARSH 5: Reproductive Health Needs Assessment of Adolescents and Young People (15-24 y): A Qualitative Study on "Perceptions of Community Stakeholders.". Indian J Pediatr. 2013;80 Suppl 2:214. http://doi.org/10.1007/s12098-013-1141-5.

33. Nair MKC, Leena ML, George B, Thankachi Y, Russell PSS. ARSH 6: Reproductive Health Needs Assessment of Adolescents and Young People (15-24 y): A Qualitative Study on "Perceptions of Program Managers and Health Providers.". Indian J Pediatr. 2013;80 Suppl 2:222. http://doi.org/10. 1007/s12098-013-1149-X.

34. Nair MKC, Leena ML, Paul MK, Vijayan Pillai H, Babu G, Russell PS, Thankachi Y. Attitude of parents and teachers towards adolescent reproductive and sexual health education. Indian J Pediatrics. 2012;79 Suppl 1:60. http://doi. org/10.1007/s12098-011-0436-7.

35. Nath A, Garg S. Adolescent friendly health services in India: A need of the hour. Indian J Med Sci. 2008;62:465-72. http://doi.org/10.4103/0019-5359. 48461.

36. Rao RSP, Lena A, Nair NS, Kamath V, Kamath A. Effectiveness of reproductive health education among rural adolescent girls: a school based intervention study in Udupi Taluk, Karnataka. Indian J Med Sci. 2008;62:439-43. http://doi. org/10.4103/0019-5359.48455

37. Sabarwal S, Santhya KG. Treatment-seeking for symptoms of reproductive tract infections among young women in India. Int Perspect Sex Reprod Health. 2012;38(2):90-8. http://doi.org/10.1363/3809012.

38. Shah SP, Nair R, Shah PP, Modi DK, Desai SA, Desai L. Improving quality of life with new menstrual hygiene practices among adolescent tribal girls in rural Gujarat, India. Reprod Health Matters. 2013;21(41):205-13. http://doi. org/10.1016/S0968-8080(13)41691-9.

39. Sharma KD, Chavan YB, Khismatrao DS, Aras RY. Male health clinic strategy in control of STI/HIV: A program review. Indian J Public Health. 2012;56:238-41.

40. Singh L, Rai RK, Singh PK. Assessing the utilization of maternal and child health care among married adolescent women: evidence from India. J Biosoc Sci. 2012;44(1):1-26. http://doi.org/10.1017/S0021932011000472.

41. Speizer IS, Nanda P, Achyut P, Pillai G, Guilkey DK. Family planning use among urban poor women from six cities of Uttar Pradesh, India. J Urban Health. 2012;89(4):639-58. http://doi.org/10.1007/s11524-011-9667-1.

42. The Centre for Development and Population Activities (CEDPA). Adolescent Girls in India Choose a Better Future: An Impact Assessment. Washington, DC. 2001. http://genderlinks.org.za/wp-content/uploads/imported/articles/ attachments/13177_file_blp_report.pdf Accessed 21 Dec 2016.

43. Mishra A, Levitt-Dayal M, \& The Centre for Development and Population Activities (CEDPA). Improving Adolescent Reproductive Health Knowledge and Outcomes through NGO Youth-Friendly Services. Washington, DC. 2003.

44. Society for Women and Children's Health and Government of India, Ministry of Health and Family Welfare. Coverage Survey on Adolescent Friendly Health Services in a District in Haryana. 2008.

45. Government of India, Ministry of Health and Family Welfare. Status of Adolescent Friendly Health Services in Haryana. 2008.
46. Centre for Operations Research and Training. Assessment of Adolescent Reproductive and Sexual Health (ARSH) Centers in Gujarat: A Report. Vadodara, India. 2008. http://www.cortindia.in/RP\%5CRP-2008-01.pdf Accessed 21 Dec 2016

47. Government of India, Ministry of Health and Family Welfare. Status of Adolescent Friendly Health Services in Karjat Block, Maharashtra. 2009

48. Institute of Health Management Research. Assessment of Adolescent Friendly Health Clinics in Rajasthan. Jaipur, India. 2010.

49. Programme Evaluation Organisation Planning Commission. Evaluation Study on National Rural Health Mission (NRHM) in Seven States: Volume II. New Delhi. 2011.

50. Pathfinder International. PRACHAR: Promoting Change In Reproductive Behavior In Bihar, India. 2011.

51. Bulliyya G, Kerketta AS. Assessment of adolescent reproductive and sexual health programme in Orissa: advocacy for intervention strategies. 2012.

52. Futures Group. Promoting adolescent reproductive health in Uttarakhand and Uttar Pradesh, India. 2012. Retrieved from http://pdf.usaid.gov/pdf_ docs/pnadz546.pdf Accessed December 21, 2016

53. Mehra S, Sogarwal R, Nair V, Satpati M, Tiwari R, Dwivedi K. Determinants of Youth Friendly Services Influencing Client Satisfaction: A Study of Client's Perspectives in India. Indian J Public Health Res Dev. 2013;4(2):221 (http:// doi.org/10.5958/j.0976-5506.4.2.047).

54. Mehra S, Sogarwal R, Chandra M. Integrating adolescent-friendly health services into the public health system: an experience from rural India. WHO South-East Asia J Public Health. 2013;2(1):6 (http://doi.org/10.4103/22243151.115828)

55. National Institute for Research in Reproductive Health (Indian Council of Medical Research). Quality Assessment of Adolescent Reproductive and Sexual Health (ARSH) Services as per the National Standards of ARSH Implementation Guide in Karjat Block of Raigad District in Maharashtra, India. 2014.

56. National Institute for Research in Reproductive Health (Indian Council of Medical Research). Establishing, Operating, Strengthening and Sustaining the Adolescent Reproductive and Sexual Health (ARSH) Services in Karjat Block of Raigad District in Maharashtra, India. 2014.

57. Jejeebhoy SJ, Santhya KG, Singh SK, et al. Provision of Adolescent Reproductive and Sexual Health Services in India: Provider Perspectives. New Delhi: Population Council; 2014. Retrieved from http://www. popcouncil.org/uploads/pdfs/2014PGY_ARSH-IndiaProviderReport.pdf. Accessed December 21, 2016.

58. Sharma P, Ingle G, Kamra S, \& Agarwal P. A Study of Gaps in Reproductive Health Services for Adolescents in Delhi. New Delhi. 2014.

59. International Center for Research on Women. Improving the Reproductive Health of Married and Unmarried Youth in India: Reproductive and Sexual Health Education, Care and Counseling for Married Adolescents in Rural Maharashtra, India. 2006. Retrieved from http://www.icrw.org/files/images/ Reproductive-and-Sexual-Health-Education-Care-and-Counseling-for-MarriedAdolescents-in -Rural-Maharashtra-India.pdf

60. Joshi BN, Chauhan SL, Donde UM, Tryambake VH, Gaikwad NS, Bhadoria V. Reproductive health problems and help seeking behavior among adolescents in urban India. Indian J Pediatr. 2006;73(6):509-13. Retrieved from (http://www.ncbi.nlm.nih.-gov/pubmed/16816513).

61. International Center for Research on Women. Improving the Reproductive Health of Married and Unmarried Youth in India: Social Mobilization or Government Services: What Influences Married Adolescents' Reproductive Health in Rural Maharashtra, India? 2006. Retrieved from http://www.icrw.org/ files/images/Social-Mobilization-or-Government-Services-What-InfluencesMarried-Adolescents-Reproductive-Health-in-Rural-Maharashtra-India.pdf

62. Society for Women and Children's Health and Government of India, Ministry of Health and Family Welfare. Coverage Survey on Adolescent Friendly Health Services in a District in Haryana. 2008.

63. Daniel EE, Masilamani R, Rahman M. The effect of community-based reproductive health communication interventions on contraceptive use among young married couples in Bihar, India. Int Fam Plan Perspect. 2008; 34(4):189-97 (http://doi.org/10.1363/ifpp.34.189.08).

64. Yadav RJ, Mehta R, Pandey A, Adhikari T. Evaluation of Adolescent-Friendly Health Services in India. Health Popul Perspect Issues. 2009;32(2):66-72.

65. Chauhan S, Joshi B, Bandiwadekar A, Barathe U, Tryambake V, Gaikwad N. (n.d.). (2010) Scaling-up adolescent friendly health services within public sector in Mumbai, India.

66. Rahman M, \& Daniel EE. A Reproductive Health Communication Model That Helps Improve Young Women's Reproductive Life and Reduce Population 
Growth: The Case of PRACHAR from Bihar, India. 2010. Retrieved from http:// hivhealthclearinghouse.unesco.org/sites/default/files/resources/bie_prachar_ impact___pathfinder_wp_jan_2010.pdf Accessed December 21, 2016.

67. PRAGYA: Multisectoral, Gendered Approach to Improve Family Planning and Sexual and Reproductive Health for Young People: A Research Study, (December). Retrieved from http://www.pathfinder.org/wp-content/ uploads/2016/10/PRAGYA-Multisectoral-Gendered-Approach-to-Improve-FPand-SRH-for-Young-People.pdf Accessed December 21, 2016.

68. Chauhan SR, Dalal AP, \& Shukla AA. Interventional study to strengthen the 'Adolescent Friendly Health Services' in anganwadis of Ahmedabad Municipal. 2012;3(4):617-622.

69. Daniel EE, \& Nanda R. The Effective of Reproductive Health Communication Interventions on Age at Marriage and First Birth in Rural Bihar, India: A retrospective study. 2012. http://www2.pathfinder.org/site/DocServer/AOM_ paper_-_full_paper_with_covers.pdf?docID=19841 Accessed 21 Dec 2016

70. Mehra S, Sogarwal R, Chandra M. Integrating adolescent-friendly health services into the public health system: an experience from rural India. WHO South-East Asia J Public Health. 2013;2(1):6 (http://doi.org/10.4103/2224-3151.115828).

Submit your next manuscript to BioMed Central and we will help you at every step:

- We accept pre-submission inquiries

- Our selector tool helps you to find the most relevant journal

- We provide round the clock customer support

- Convenient online submission

- Thorough peer review

- Inclusion in PubMed and all major indexing services

- Maximum visibility for your research

Submit your manuscript at www.biomedcentral.com/submit
Biomed Central 